2016-01

Dynamics of rip currents associated with groynes field measurements, modelling and implications for beach safety

Scott, Tim

http://hdl.handle.net/10026.1/8520

10.1016/j.coastaleng.2015.09.013

Coastal Engineering

Elsevier BV

All content in PEARL is protected by copyright law. Author manuscripts are made available in accordance with publisher policies. Please cite only the published version using the details provided on the item record or document. In the absence of an open licence (e.g. Creative Commons), permissions for further reuse of content should be sought from the publisher or author. 


\title{
DYNAMICS OF RIP CURRENTS ASSOCIATED WITH GROYNES - FIELD MEASUREMENTS, MODELLING AND IMPLICATIONS FOR BEACH SAFETY
}

\author{
Coastal Engineering \\ http://dx.doi.org/10.1016/j.coastaleng.2015.09.013
}

\author{
Tim Scott ${ }^{\mathrm{a}^{*}}$, Martin Austin ${ }^{\mathrm{b}}$, Gerd Masselink $^{\mathrm{a}}$ and Paul Russell ${ }^{\mathrm{a}}$ \\ ${ }^{a}$ School of Marine Science and Engineering, Plymouth University, Drake Circus, Plymouth PL4 8AA, UK \\ ${ }^{\mathrm{b}}$ School of Ocean Sciences, Bangor University, Menai Bridge, Anglesey LL59 5AB, UK \\ ${ }^{*}$ Corresponding author: tel +44 1752586128 \\ E-mail address: timothy.scott@plymouth.ac.uk (T Scott)
}

\section{INTRODUCTION}

Rip currents can occur around groynes and other coastal structures (e.g. breakwaters and geological headlands) which provide a boundary to the wave-induced flow field. The occurrence of boundarycontrolled controlled rips and the strength of the associated flows depend primarily on a combination of the dynamic forcing factors (primarily wave characteristics) and the static controlling factors (location, dimensions and characteristics of the topographic feature, e.g., length of groyne, shape of the headland). The generation of boundary-controlled rips is conceptually explained by the seaward deflection of a strong longshore current upstream of the structure (Castelle end Coco, 2013). Such longshore currents are most commonly associated with obliquely-incident wave approach, but can also be generated by an alongshore gradient in the wave energy level (driving an alongshore pressure gradient due to wave setup).

The research presented here focuses on rip currents around a groyne field, which are commonly located on drift-aligned coasts susceptible to coastal erosion (e.g., van Rijn, 2011), but the findings relate to any obstruction in the surf zone of similar permeability and scale. Whilst the presence of rip currents both on the upstream and downstream flanks of groynes is regularly supported anecdotally in literature (e.g., Short, 1992; Kraus et al., 1994), very few field measurements (with the exception of Pattiaratchi et al., 2009) exist in literature of their presence and dynamics. In the case of groynes in fetch-limited environments there are no published field measurements to our knowledge.

Most laboratory and field studies into rip current generation around groynes focus on the presence of a pressure gradient driven cell circulation forming on the downstream side of the groyne due to alongshore gradients in wave height, and hence wave setup, due to diffraction and wave shadowing (Gourlay, 1974; Bowen and Inman, 1986). In contrast, modelling work around groyne fields in fetchlimited seas using Delft3D (van Rijn et al., 2011) suggests that the dominant offshore-directed current occurs through the deflection of the longshore current on the upstream side of the groyne. These modelling results further show that under oblique wind wave conditions $\left(H_{s}=1 \mathrm{~m} ; T_{p}=5 \mathrm{~s} ; \alpha=15^{\circ}\right)$, a key geometric control on circulation is the ratio of groyne spacing to groyne length $\left(L_{s} / L_{g}\right)$. In particular, decreasing $L_{s} / L_{g}$ reduces circulation velocities within the cells, while increasing $L_{s} / L_{g}$ results in the reestablishment of longshore currents within the cells and an increase in offshore-directed currents. Van Rijn et al. (2011) also recognize the significance of the ratio of groyne length to surf zone width $\left(L_{g} / X_{b}\right)$ as a control on sediment bypassing, but little is known about the impact of $L_{g} / X_{b}$ on rip flows. 


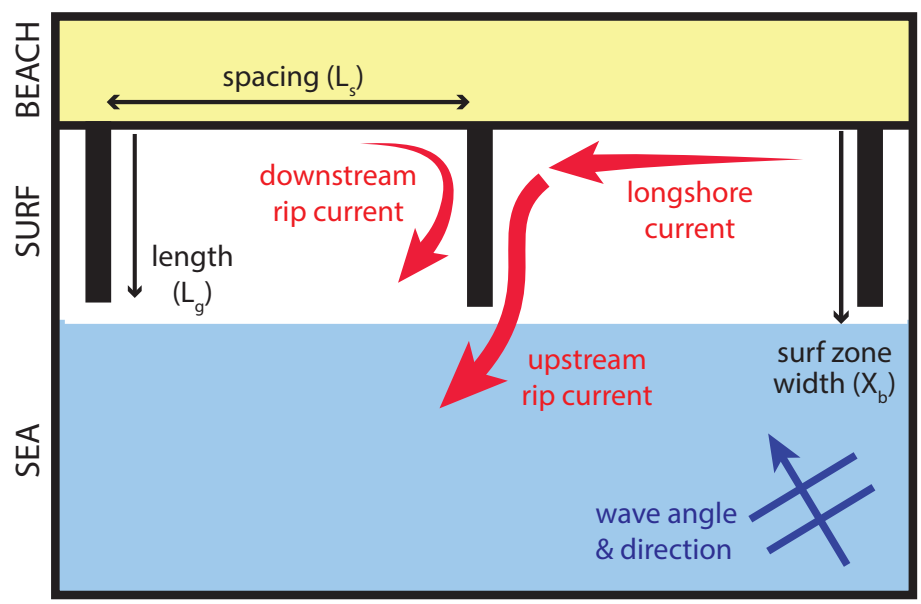

Figure 1 - Schematic of principal topographic rip circulations and parameters governing the geometry of the topographic obstruction.

Recent modeling studies by Castelle and Coco (2013) of boundary-controlled rip currents associated with rocky headlands and embayed beaches (where $L_{g} / X_{b} \approx 2$ ) are also of relevance to the present investigation. They provide a 'scaled up' version of a similar problem on high-energy fetch-unlimited coasts. Their modeling results indicated that under oblique swell-wave conditions, the upstream (upwave) rip currents generated are the main mechanism for the exchange of floating material offshore, while the downstream (downwave) rip re-circulates within the surf zone, similar to observations by Pattiaratchi et al. (2009). This held true as long as $L_{s}$ offered a sufficient distance for a longshore current to develop. In narrow embayed beaches the upstream rip became the dominant feature and the most significant offshore exchange mechanism.

Flow characteristics around groynes are of obvious and significant interest to coastal engineers, because the ability of groyne fields to retain sediment is directly linked to the degree of hydrodynamic communication between the groyne embayments: if there are no (strong) flows around groynes it is likely that sediment will (not) be retained. Strong offshore rip flows acting near groynes may also be a significant conduit for transporting sediment offshore. The length, spacing and permeability of the structures are important considerations in the design of groynes and groyne fields and these factors all have a bearing on the development of topographic rip currents, as demonstrated by the modelling of van Rijn et al. (2011).

Boundary-controlled rip currents are also important because they present a hazard to water users worldwide and are demonstrably a key environmental cause of incident on beaches in the UK patrolled by the Royal National Lifeboat Institution (RNLI). According to the RNLI (Scott et al., 2014), over the period 2006-2011, 66\% of all water-based incidents on RNLI patrolled beaches were due to rip currents (12,521 incidents) with $21 \%$ of all rip incidents involving boundary-controlled rips (2,629 incidents). Of all recorded rip incidents over this period, 561 were recorded as lives saved (i.e., without assistance the surf zone user would have drowned) and lives saved associated with boundary-controlled rips (geology and man-made structures) made up $26 \%$ of all rip-related lives saved recorded (143). This proportion of lives saved is more than for all other rip incidents, suggesting that boundary-controlled rip incidents were more severe (32\% greater potential for lives lost) than those associated with other recorded rip incidents. 
Boundary-controlled rip currents are very common in the UK, and indeed along many of the world's coastlines. For example, $74 \%$ of all beaches in the UK are classified as being modified by coastal structures; $33 \%$ have groynes; $21 \%$ have breakwaters; $62 \%$ have natural geological outcrops; and $56 \%$ have headlands (Scott, 2009) - these are all features that have the potential to create boundarycontrolled rip currents. If the RNLI incident statistics from patrolled beaches are therefore extrapolated to non-patrolled beaches, it is evidently clear that rips associated with physical hazards are likely to be a major factor in coastal drowning.

The aim of this research is to gain new scientific insight and practical beach safety understanding of boundary-controlled rip currents that occur around coastal structures (e.g., groynes, breakwaters), specifically those located in fetch-limited seas. The principal research aims are: (1) to quantify measured and simulated rip current behavior (rip flow speed and spatial extent) around a groyne field throughout a range of environmental forcing conditions; and (2) to further explore the impact groyne field geometries have on rip current dynamics throughout a broad parameter space for two important non-dimensional variables $L_{g} / X_{b}$ and $L_{s} / L_{g}$.

\section{FIELD SITE}

Rip currents and nearshore hydrodynamics around a groyne field were measured over a 10-day field experiment at Boscombe beach, located in Poole Bay on the south coast of England (Figure 2). Boscombe is a linear subtidal barred beach (Scott et al., 2011) with a median sediment size $\left(D_{50}\right)$ of $0.28 \mathrm{~mm}$. The beach at Boscombe has a relatively steep reflective upper beach $(\tan \beta=0.06)$ and flatter more dissipative intertidal low-tide terrace $(\tan \beta=0.03)$. The subtidal beach is characterised by a linear subtidal bar (Figure 3) over which wave breaking occurs at low water under medium-high energy waves (typically when $H_{s}>1 \mathrm{~m}$ ). Boscombe beach is part of a longer section of a continuous south-facing beach stretching from Poole to Southbourne $(15 \mathrm{~km})$. This coastline is characterized by extensive groyne fields that are typical of those found throughout the drift-aligned coasts of the UK. The groyne system at the Boscombe field site has an average longshore groyne spacing $\left(L_{s}\right)$ of $200 \mathrm{~m}$ with a design length of $70 \mathrm{~m}$ from groyne tip to the promenade, but a typical active groyne length $\left(L_{g}\right)$ from shoreline to groyne tip of $50 \mathrm{~m}$ giving a groyne spacing to length ratio $L_{s} / L_{g}$ of 4 . The beach at Boscombe is known to have intermittent boundary-controlled rip current generation around the groyne systems. RNLI lifeguard incident records for the period 2006-2011 show that 496 individuals have been involved in rip current incidents in Poole Bay.

The wave climate at Boscombe is dominated by locally-generated wind waves with a small amount of Atlantic swell wave energy penetrating up the English Channel from the west. It is a low-energy wave environment that experiences intermittent medium-high energy wind waves from a variety of directions (SE-SW). Wave statistics from data collected by a Datawell directional wave-rider buoy at Boscombe, moored in $10 \mathrm{~m}$ water depth (refer to Figure 2), for the period 2003-2012 are shown in Table 1. The annual mean significant wave height $\left(H_{s}\right)$ is $0.53 \mathrm{~m}$ with a peak $\left(T_{p}\right)$ wave period of $7.1 \mathrm{~s}$. While monthly mean values of peak wave direction $\left(D_{p}\right)$ are typically close to shore normal $\left(180^{\circ}\right)$, the mean standard deviation $(\sigma)$ is $21.3^{\circ}$. On average, the wave angle from shore normal $(\alpha)$ is greater than $10^{\circ}$ for $66 \%$ of the time. Boscombe is classified as microtidal, and has a mean spring tide range of $1.5 \mathrm{~m}$, with mean low and high water spring tide levels of -0.9 and $0.6 \mathrm{~m}$ ODN (Ordnance Datum Newlyn), respectively. The tidal range is small in the context of the UK environment. 

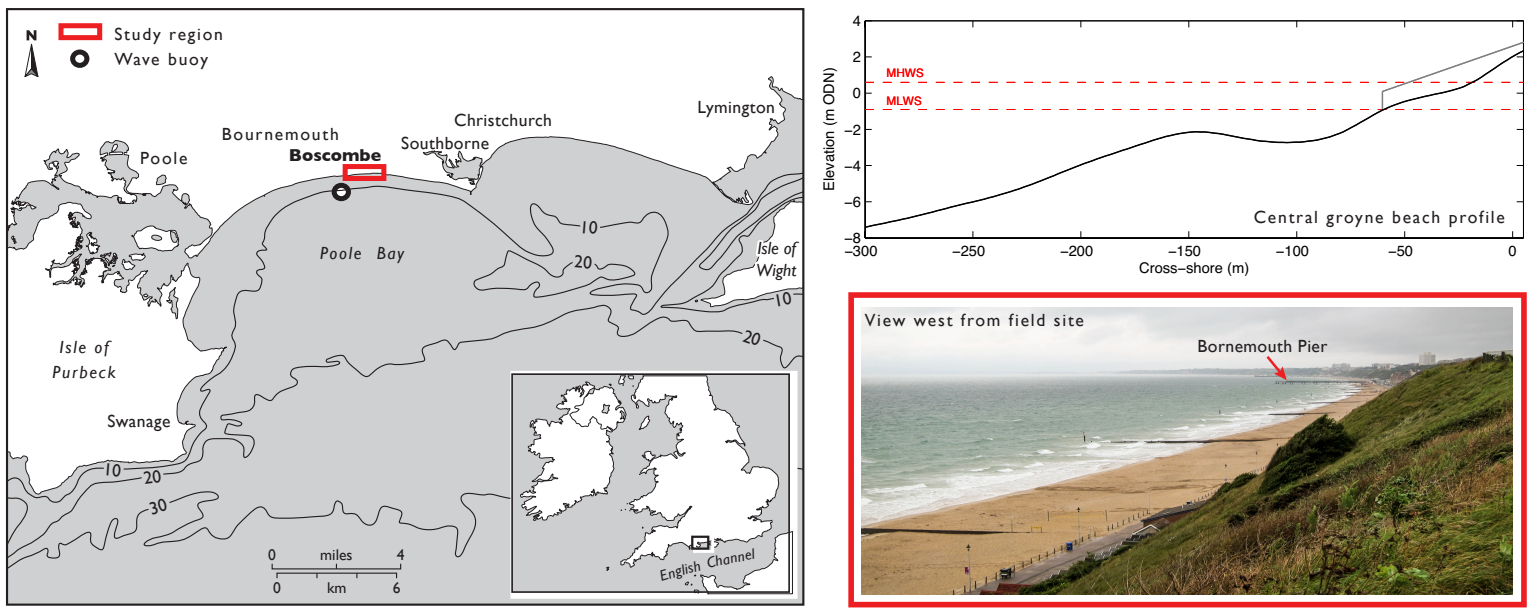

Figure 2 - Map of the study area, showing location of directional wave buoy (black circle) and offshore bathymetry (left panel), an alongshore-averaged beach profile with the central groyne dimensions indicating mean tidal levels (upper right panel), and a photographic example of the coastline to the west of study site, showing the extensive groyne field and Boscombe Pier (lower right panel).

Table 1 - Mean wave statistics for Boscombe beach for the period 2003-2012, taken from the nearshore Boscombe Datawell Mark 3 wave-rider buoy maintained by the Channel Coastal Observatory. The buoy position is 50 $42.681^{\prime} \mathrm{N} 001^{\circ} 50.376^{\prime} \mathrm{W}$, approximately $700 \mathrm{~m}$ from the end of Bournemouth Pier.

\begin{tabular}{|l|c|c|c|c|c|}
\hline Month & $\boldsymbol{H}_{\boldsymbol{s}}(\mathbf{m})$ & $\boldsymbol{T}_{\boldsymbol{p}}(\mathbf{s})$ & $\boldsymbol{D}_{\boldsymbol{p}}\left(^{\circ}\right)$ & $\boldsymbol{\sigma}\left(^{\circ}\right)$ & $\boldsymbol{\alpha}>\mathbf{1 0}^{\mathbf{\circ}}(\mathbf{\%})$ \\
\hline January & 0.7 & 9.1 & 179 & 22.0 & 64 \\
\hline February & 0.53 & 9.4 & 177 & 21.1 & 62 \\
\hline March & 0.49 & 8.3 & 179 & 22.9 & 64 \\
\hline April & 0.41 & 7 & 179 & 23.5 & 67 \\
\hline May & 0.44 & 6.2 & 177 & 23.3 & 68 \\
\hline June & 0.41 & 5.7 & 181 & 21.4 & 68 \\
\hline July & 0.46 & 5.4 & 185 & 18.1 & 61 \\
\hline August & 0.44 & 5.5 & 183 & 19.2 & 59 \\
\hline September & 0.47 & 6.5 & 179 & 21.9 & 68 \\
\hline October & 0.64 & 6.6 & 176 & 22.6 & 70 \\
\hline November & 0.68 & 7.5 & 179 & 22.1 & 66 \\
\hline December & 0.65 & 8.2 & 178 & 18.0 & 71 \\
\hline
\end{tabular}




\section{METHODOLOGY}

\subsection{Field measurements}

A comprehensive field dataset of Lagrangian and Eulerian measurements of rips currents and relevant boundary conditions were collected around a groyne field at Boscombe beach over a period of 9-days during October 2012. The beach morphology around the groyne field was surveyed with RTK-GPS throughout a region $1000 \times 600 \mathrm{~m}$ region (alongshore and cross-shore, respectively), extending to beyond the $10 \mathrm{~m}$ ODN depth contour (Figure 2). The 3D intertidal beach morphology was surveyed every low tide ( $10 \mathrm{~m}$ spacing) and sub-tidal bathymetric data were collected at the beginning of the experiment, using jetski-mounted RTK-GPS and a single-beam echo-sounder (cross-shore transects 25-m separation).

Four in-situ instrument rigs were deployed around a groyne/embayment system over a 9-day period from 02/10/2012 to 10/10/2012, measuring currents, waves and tides (Figure 3). Two rigs (R1 and R2) were deployed either side of the groyne, offset by c. $5 \mathrm{~m}$ in the alongshore and deployed at a bed elevation of $-0.6 \mathrm{~m}$ ODN to measure the waves/current and rip flows adjacent to the structure. Each rig had a three-dimensional acoustic Doppler velocimeter (3D-ADV) with sensor elevation of $0.28 \mathrm{~m}$ above the bed and a high-precision pressure transducer (PT). The third rig (R3) was located in the middle of the eastern embayment, offset by c. $100 \mathrm{~m}$ from the groyne in the alongshore and deployed at a bed elevation of -1.7 m ODN, and the fourth rig (R4) was deployed c. $12 \mathrm{~m}$ seaward of the terminal end of the groyne at a bed elevation of $-1.8 \mathrm{~m}$ ODN to measure the flow field away from the end of the groyne. R3 and R4 were also equipped with 3D-ADVs, with sensor elevations $0.55 \mathrm{~m}$ above the bed, and a highprecision PT. All instruments were self-recording and burst-sampled at $4 \mathrm{~Hz}$, providing 8.5 min of data every $10 \mathrm{~min}$. The three rigs R1, R2 and R4 were located to obtain optimum coverage of the current field and rip flows around the groyne-embayment system with R3 providing data on the mid-embayment conditions as far away as possible from any structural influence. Rigs R1 and R2 intermittently dried for short periods around the lowest tides, whereas rigs R3 and R4 were permanently submerged.

Wave and tidal data were also collected using two RBR-TWR 2050 tide and wave recorders (P1 and P2) logging continuously at $1 \mathrm{~Hz}$. The pressure transducers were deployed off the end of the groyne at a distance of c. $30 \mathrm{~m} \mathrm{(P1)} \mathrm{and} \mathrm{c.} 140 \mathrm{~m}$ (P2), respectively. P1 was located at a depth of $-2.5 \mathrm{~m}$ ODN in the trough between the low-tide terrace and the offshore bar, and P2 was deployed at a depth of $-4.25 \mathrm{~m}$ ODN seaward of the offshore bar. A Datawell directional wave-rider buoy moored in c. $10 \mathrm{~m}$ water depth offshore of Boscombe Pier, c. $1.7 \mathrm{~km}$ alongshore to the east of the field site, provided directional offshore wave data during the field experiment (Figure 1).

Six GPS-tracked surf zone drifters were deployed during selected daytime tidal cycles to record the Lagrangian currents around the groyne and within the groyne embayment. The drifters were of a robust design modified from that of Schmidt et al. (2003) and have previously been used to record flows associated with beach rips by MacMahan et al. (2009), Austin et al. (2012) and Scott et al. (2013). The GPS units logged raw L1 GPS carrier-phase information at $1 \mathrm{~Hz}$. These raw GPS data were then postprocessed to provide an accuracy of $0.4 \mathrm{~m}$ in horizontal position and $0.01 \mathrm{~m} \mathrm{~s}^{-1}$ in velocity. Following Murray (1975), the effects of wind slippage were computed giving a maximum windage error of $<0.08 \mathrm{~m}$

$\mathrm{s}^{-1}$ during drifter deployments, where the maximum wind speed was $7.2 \mathrm{~m} \mathrm{~s}^{-1}$. Drifter bodies are fitted with a damping plate and fins that sit $0.45 \mathrm{~m}$ below the water surface to minimize surfing behavior (Figure 4). In multiple surf zone tests, released drifter units compare well with dye release, effectively tracking dye plumes within a well-mixed surf zone environment (Figure 4). 

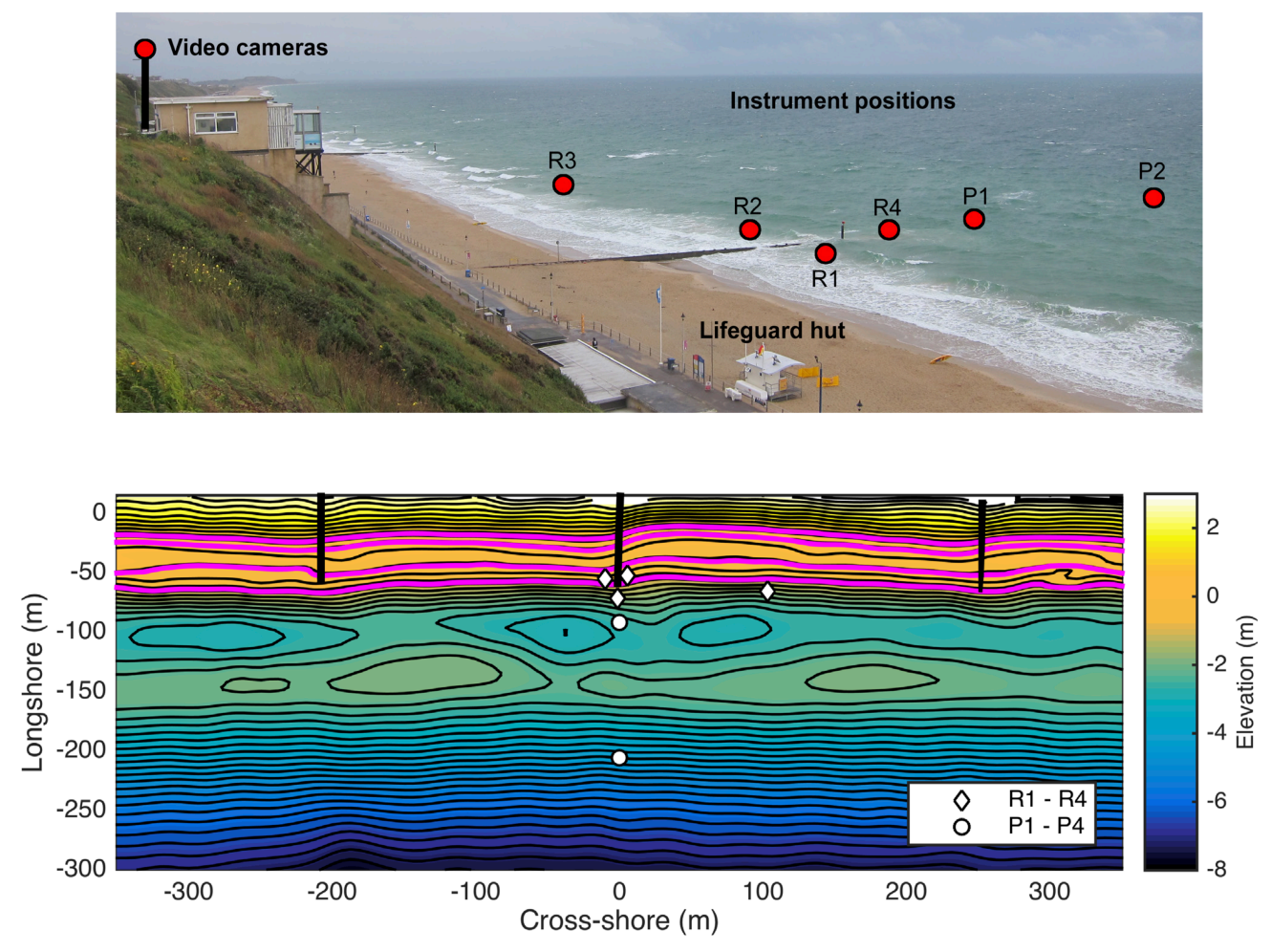

Figure 3 - Photo of the study site with instrument locations (upper right panel); and beach morphology surveyed on 20/12/2012 with location of instrumentation (lower panel). In the lower panel, red contours are mean tidal levels (MHWS, MHWN, MLWN and MLWS); white boxes are locations of instrument rigs ( $R$ is current meter and pressure transducer; $P$ is only pressure transducer); bold black lines are beach groynes; and black contours are at 0.25- $m$ separation.

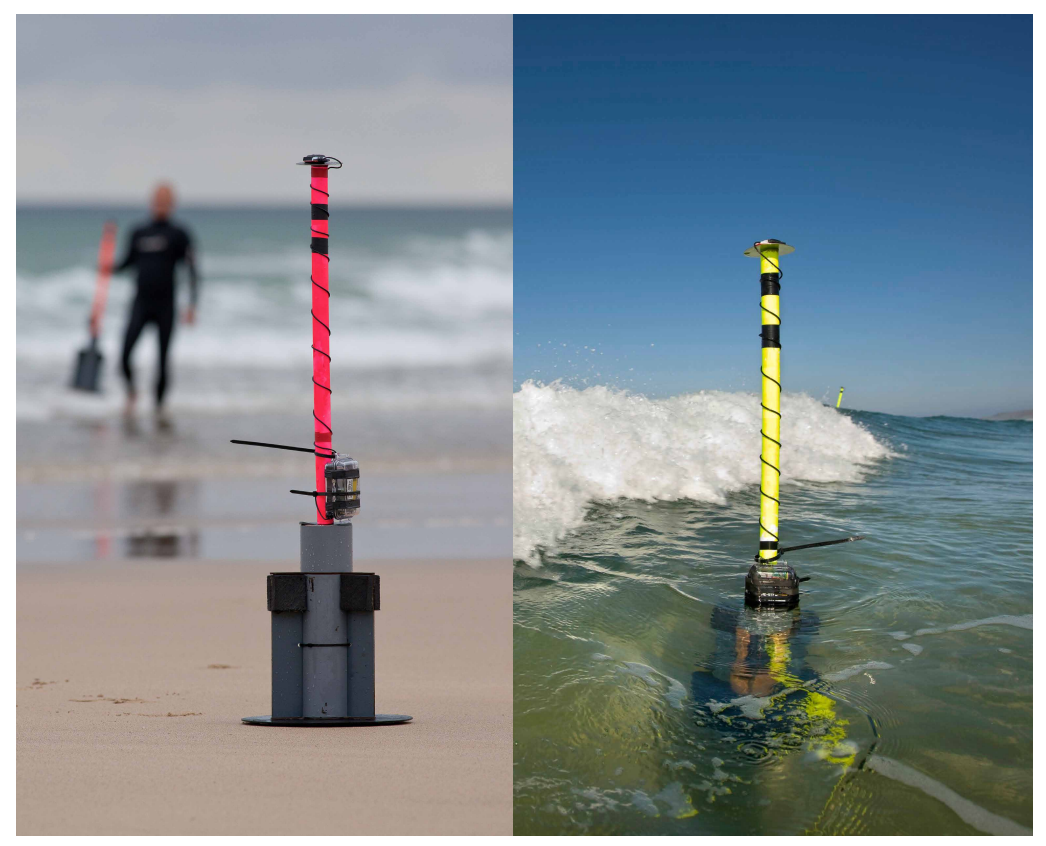

Figure 4-GPS drifter unit. Drifter body is constructed of a buoyant chamber with a damping plate and fins to reduce surfing. When floating, only the coloured mast is visible on top of which is the GPS antenna attached to a ground plane. Steel ballast plate ensures quick righting and minimum signal loss due to waves. GPS unit is secured in a waterproof box fixed the mast. 
Drifters were deployed for up to 2 hours either side of high tide, when the topographic rips were at their most active and the groyne protrusion into the surf zone was maximal. The drifter units were continuously 'seeded' throughout the mid and outer surf zone, at least half an embayment width upstream of the groyne. Drifters were deployed and removed from the surf zone manually by the field team with drifters removed and redeployed after they either washed up on the beach or exited a defined region. The typical extent of the drifter deployment region was c. $400 \mathrm{~m}$ in the alongshore and c. $200 \mathrm{~m}$ in the cross-shore. In total, there were eight deployments, providing almost 20 hours of Lagrangian data. Mean drifter velocities during each of the deployments were calculated throughout a $10 \times 10 \mathrm{~m}$ spaced regular grid across the domain. Computational procedures are described in detail in MacMahan et al. (2010) and Austin et al. (2012).

A temporary video system, consisting of two cameras, was erected on the cliff top above the beach at an elevation of c. $30 \mathrm{~m}$ ODN and collected a suite of image products every 30 minutes. Images were merged and rectified to provide plan-view timex (10-min time-averaged) products. For each timex image, crossshore positions of the shoreline and offshore surf zone limit were manually extracted for a range of alongshore positions. These data were used to determine surf zone width $\left(X_{b}\right)$ from the upstream embayment for each deployment.

\subsection{Numerical modelling}

The open source XBeach model was used to compute the flow characteristics around the groyne field. XBeach was developed for modelling extreme storm response on sandy beaches (cf., Roelvink et al., 2009), but is also widely used to model surf zone hydrodynamics (Austin et al., 2012). XBeach solves coupled 2D horizontal for wave propagation, flow, sediment transport and bed level changes. The model includes a non-stationary wave driver with directional spreading, which accounts for wave-group generated surf motions and solves Generalised Lagrangian Mean flow velocities, accounting for Stokes Drift, all of which are important for accurately simulating rip current dynamics. XBeach has a successful track record of being used, within a similar hybrid field observation/modeling approach, to accurately simulate beach rip current flows by Austin et al. (2012; 2014).

The model bathymetry used was based on the combined topographic and bathymetric survey data measured at Boscombe (Figure 3). An alongshore-averaged beach profile was defined (Figure 2), extending $660 \mathrm{~m}$ offshore from the promenade to c. $11 \mathrm{~m}$ water depth, with 5-m cross-shore spacing. This was subsequently replicated in the alongshore direction with $5-\mathrm{m}$ grid spacing to produce a twodimensional model domain with a total size of $[X, Y]=660 \times 1000 \mathrm{~m}$. Groynes were added to the model domain by specifying impermeable structures at the required cross- and alongshore locations, with the groyne elevation and thickness as measured at Boscombe. Groyne length and spacing were initially specified to replicate the observed case, but were subsequently modified for scenario tests. An alongshore uniform bathymetry was used because both (1) the measured topography/bathymetry was insufficient to create a suitable model domain with appropriate spatial resolution around embayment structures and limited extent offshore and alongshore of the field site; and (2) to enable the implementation of variable embayment geometries (groyne spacing and length) for which an idealized alongshore-mean beach profile was required, as subtle embayment morphology that existed within the real groyne embayments would only relate to the groyne geometries at the Boscombe field site.

The wave conditions at the offshore boundary of the XBeach model were described by a parametric JONSWAP spectrum using $H_{s}=0.25-1.5 \mathrm{~m}, \alpha=0-45^{\circ}, T_{p}=0.2 \mathrm{~Hz}$ and $30^{\circ}$ of directional spreading. The spectral frequency resolution was $0.005 \mathrm{~Hz}$, with an upper frequency of $1 \mathrm{~Hz}$ and a JONSWAP peak enhancement factor of 3.3. The wave directional resolution of the model domain was 5 degrees. Wave heights and periods were defined from the field observations. The tidal level was varied during the 
simulations and wind forcing was included in the model - both were defined based on field the observations.

The XBeach model has a number of free parameters that are used to calibrate the model. In our hydrodynamic-only mode, these govern parameterizations in the short-wave hydrodynamics and flow. The hydrodynamics of the model were calibrated with measured Eulerian data and the simulated nearshore circulation patterns (flow speeds, directions and spatial extents) were validated against realworld Lagrangian drifter measurements. Multiple model simulations were run, forced by directionallyspread spectral wave characteristics from 8 October 2012, and the key free model parameters that control the wave breaking were adjusted to minimise the residuals between the model output and the field data (along a central cross-shore transect). The highest level of model skill was achieved with a gamma value, which controls the depth of wave breaking, of $\gamma=0.4$, and a beta value, which controls the steepness of the wave roller and hence intensity of breaking, of $\beta=0.2$.

\section{RESULTS}

\subsection{Environmental conditions}

Offshore and inshore wave conditions encountered during the field experiment, and measured by the directional wave buoy and P2, respectively, are shown in Figure 5. The unusual tidal oscillation found in Poole Bay, characterised by a double high tide most days and a microtidal tide range, is illustrated. The wave conditions were typical of the long-term average at Boscombe (October mean $H_{s}=0.64 \mathrm{~m}$ ) with a mean offshore (inshore) significant wave height during the experiment of $0.7 \mathrm{~m}(0.5 \mathrm{~m})$. The variability in observed conditions was also typical of fetch-limited coasts in the UK, with prevailing low-energy wave conditions (2, 4, 6, 7, 9 and 10 October), interspersed with short high-energy wave events that were typically associated with locally generated wind seas (3,5 and 8 October). The maximum significant offshore and inshore wave height were recorded on 5 October and were $2.11 \mathrm{~m}$ and $1.63 \mathrm{~m}$, respectively.

A feature of many semi-sheltered coasts, such as Poole Bay, is the relatively short significant wave period $\left(T_{s}=5-10 \mathrm{~s}\right)$ with the occasional influence of longer period swell into the incident wave spectrum, creating a bi-modal frequency spectrum. A bi-modal wave spectrum was observed during 7 and 9 October. Depending on the relative energy levels of the wind sea and the swell, the peak wave period can be seen to fluctuate considerably over this period with $T_{p}$ ranging from $5 \mathrm{~s}$ to $15 \mathrm{~s}$.

The wave direction during the first part of the experiment, from 2 to 6 October, was SSW $\left(D_{p}=180-\right.$ $210^{\circ}$ ), but the relatively high-energy wave event that occurred on 8 October with inshore $H_{s}$ almost reaching $1 \mathrm{~m}$, was characterised by waves from the SE $\left(D_{p}=110-140^{\circ}\right)$. The variability in the incident wave direction is important, because these wave direction changes are associated with reversals in the alongshore current direction, thereby changing the dynamics of boundary-controlled rips.

\subsection{Hydrodynamic observations}

The time-averaged water level, wave conditions and Eulerian flow velocities over the 8-day measurement period from 2 to 9 October are plotted in Figure 6. R1 and R2 were deployed in relatively shallow water at either side of the groyne and mainly measured cross-shore flow velocities $(u)$; R4 was deployed off the tip of the groyne and recorded a mixture of cross-shore and alongshore flows ( $u$ and $v$ ); and R3 was installed in the center of the embayment, as far away as possible from structural influence, and measured mainly alongshore flows (v). The velocity time series are, unfortunately, not continuous: (1) data are missing from R1 and R2 for 4 and 5 October because the instrument rigs were removed as a 

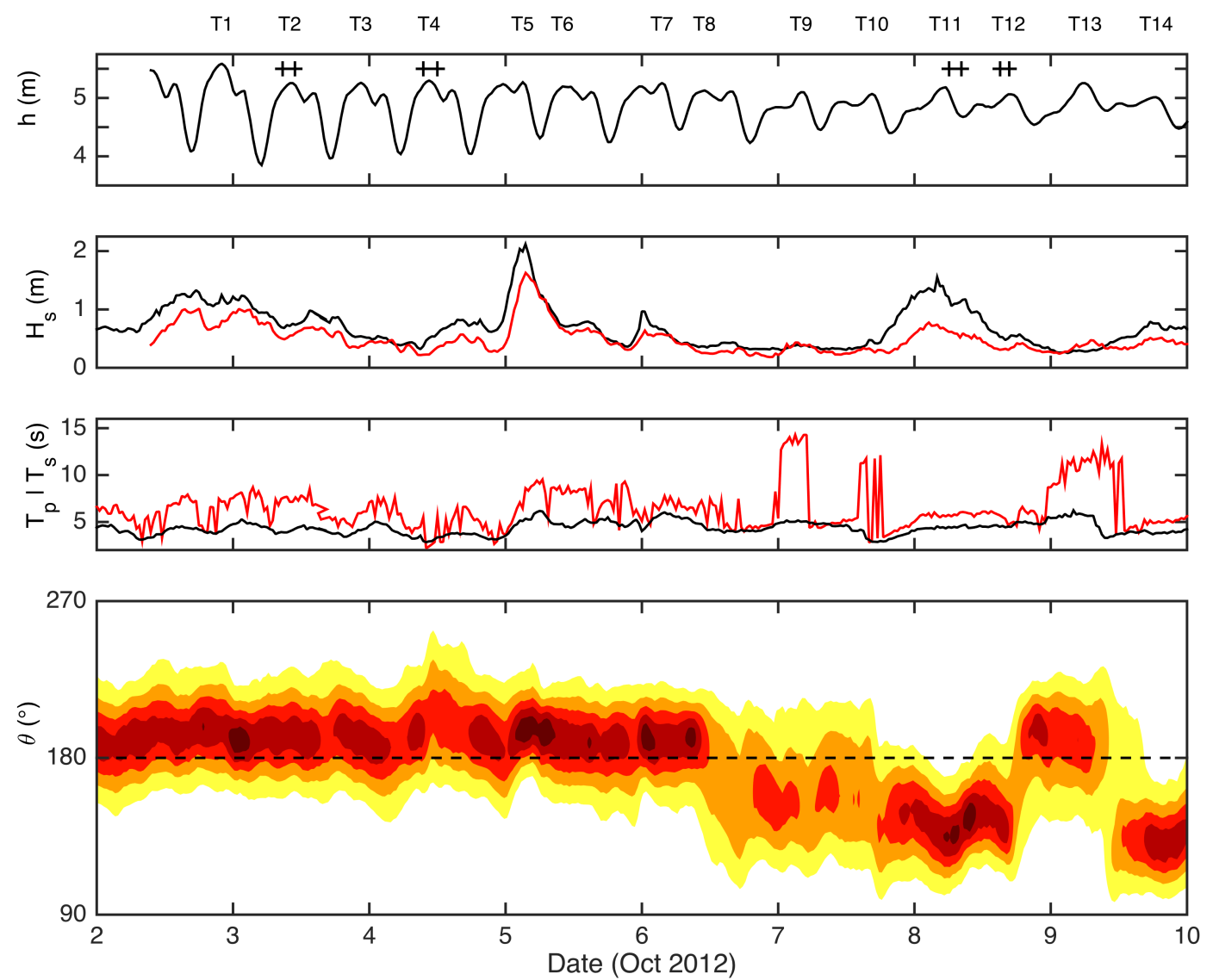

Figure 5 - Water level and wave characteristics during the field deployment. From top to bottom: mean water depth ( $h$ ) measured by P4; offshore (directional wave buoy; black line) and inshore (P4; red line) significant wave height $\left(\mathrm{H}_{\mathrm{s}}\right)$; offshore peak ( $\mathrm{T}_{\mathrm{p}}$; red line) and significant $\left(\mathrm{T}_{\mathrm{s}}\right.$; black line) wave period; offshore normalised directional wave spectrum ( $\left.\mathrm{S}_{\theta}\right)$. Normalised spectral energy runs from 0 to 1 (white to red). Shore normal at Boscombe is $180^{\circ}$ as marked on the lower panel. Measurements included 14 high tides, which are labeled as T1 - T14 above the top panel. Four events are marked with shaded regions (T2, T4, T11 and T12); these will be referred to later when discussing the current measurements. Note the shift from SSW waves during the first half of the period to SE waves during the latter phase.

precaution against the high-energy waves expected for the early morning on 5 October; and (2) data are missing from R4 for 8 and 9 October because the instrument became buried by sand.

Three high-energy wave events occurred during the field experiment $(3,5$ and 8 October; Figure 5 and 5). Longshore current measurements from both R3 and R4 show strong eastward flows during the first two events $\left(v=0.2-5 \mathrm{~m} \mathrm{~s}^{-1}\right.$ for R3; $v=0.5-1 \mathrm{~m} \mathrm{~s}^{-1}$ for R4), which were associated with a wave angle to the west of shore-normal $\left(D_{p}=180-210^{\circ}\right)$. The third high-energy event was associated with a change in wave angle to the east of shore-normal $\left(D_{p}=110-140^{\circ}\right)$ and induced a reversal in alongshore current direction to a westward flow. Both R3 and R4 recorded a change in flow direction, but flow measurements from R4 experienced the largest increase in alongshore velocity and peaked at $v=0.4 \mathrm{~m}$ $\mathrm{s}^{-1}$ when the current meter became buried by sand. During the second and third high-energy event ( 5 and 8 October), significant offshore-directed velocities were recorded by R3 with a maximum of $u=0.3$ $\mathrm{m} \mathrm{s}^{-1}$ recorded just before the current meter became buried. This suggests the presence of a relatively strong topographic rip current more than $10 \mathrm{~m}$ seaward from the tip of the groyne. 

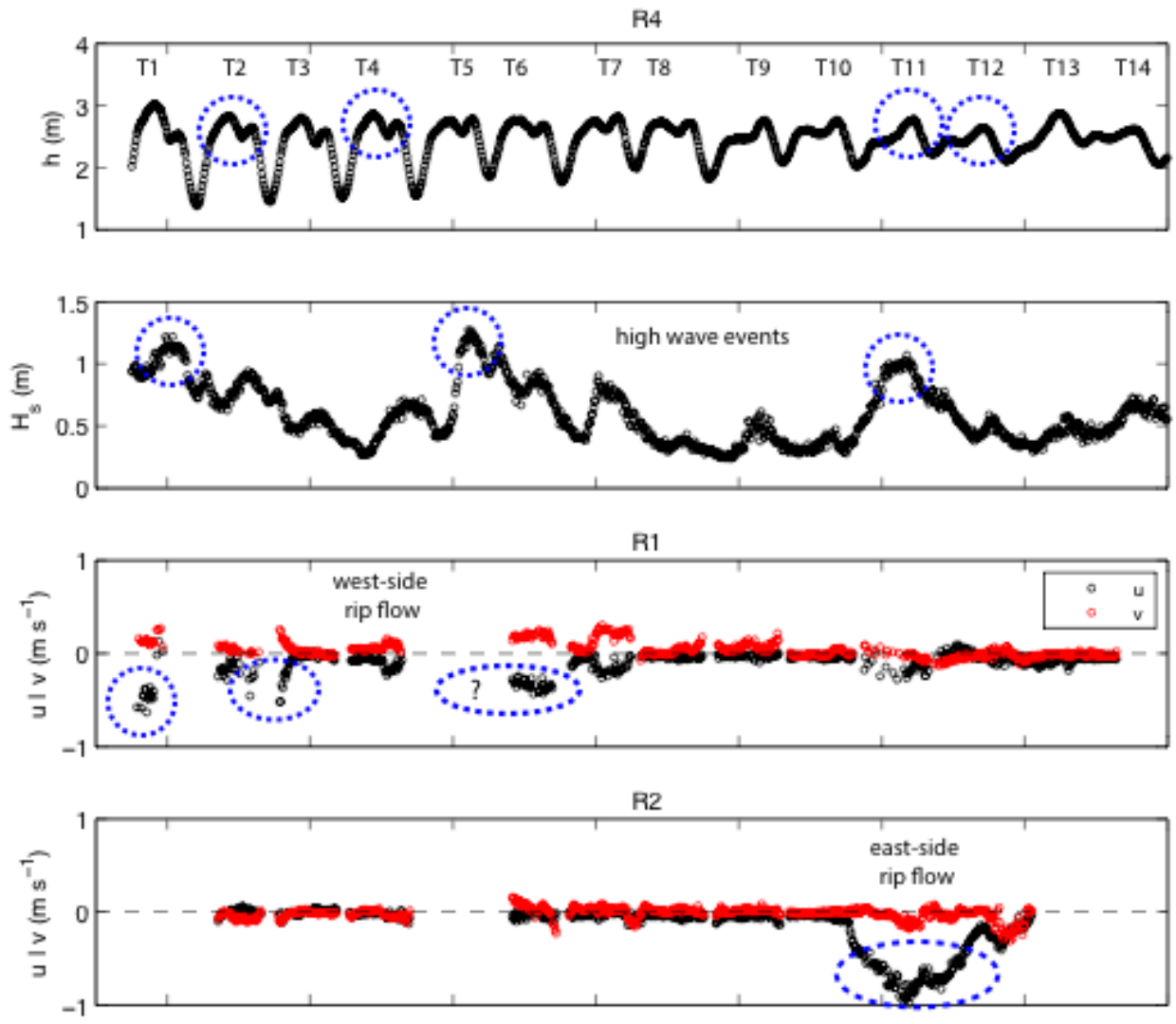

$\mathrm{R3}$
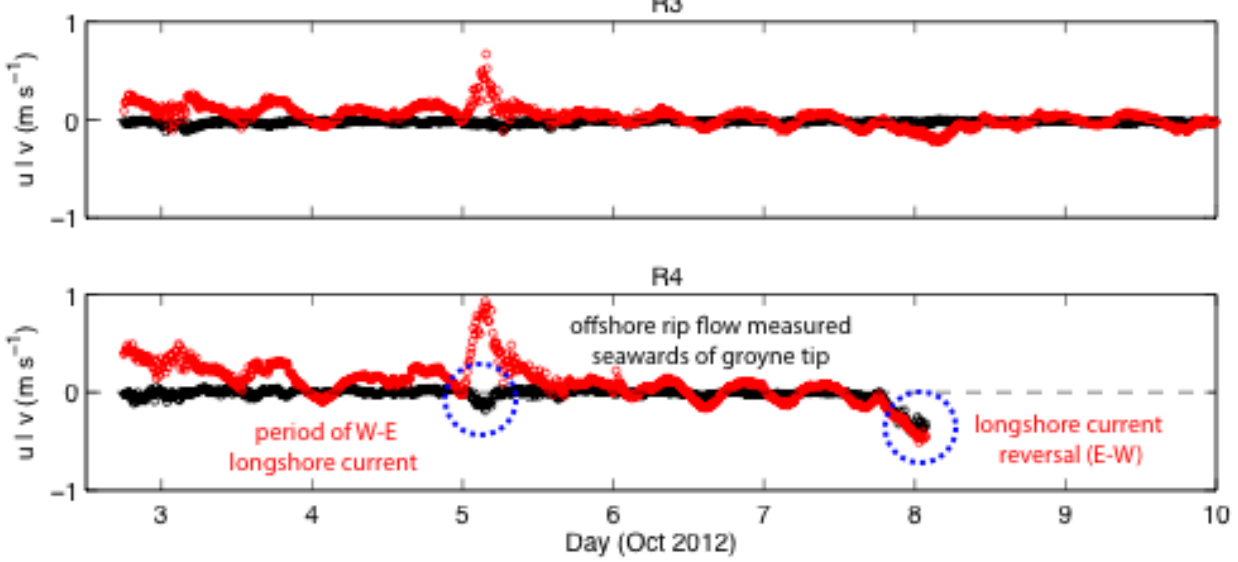

Figure 6 - Water depth ( $h$ ), inshore significant wave height $\left(H_{s}\right)$, and cross-shore $(u)$ and longshore $(v)$ current velocities recorded by, from top to bottom, $R 1, R 2, R 3$ and $R 4$. The mean flow velocities represent 10-min averages and negative $u(v)$ values represent offshore (westward) currents. Blue dashed circles indicate specific events referred to by annotations and in the text.

Strong offshore-directed rip current flows $\left(u>0.4 \mathrm{~m} \mathrm{~s}^{-1}\right)$ were recorded adjacent to the groyne structure by R1 and R2 during four periods, associated with T2, T4, T11 and T12 (Figure 6). Maximum flow speedsof $u=0.5 \mathrm{~m} \mathrm{~s}^{-1}$ and $u=1 \mathrm{~m} \mathrm{~s}^{-1}$ were recorded by R1 and R2, respectively. With the exception of the last period (T12), observed rip flows only occurred on the updrift side of the groyne and were clearly associated with the seaward deflection of the alongshore current within the updrift groyne embayment. During T12, an additional, albeit weaker, rip flow was observed on the downdrift side of the groyne. This offshore current was associated with the seaward deflection of the alongshore current within the downdrift groyne embayment, probably related to an alongshore gradient in the wave height due to wave shadowing (cf. Figure 1). Interestingly, $u$ and $v$ are correlated at the updrift rig (R1) during westside rip flow but are not correlated at R2 during east-side rip flow, due to the angle of the offshore- 
directed rip flow. The antecedent conditions at Boscombe were W-E drift, which led to the updrift side of the groyne having a smaller relative groyne length compared to the downdrift side (observed as differing HW shoreline positions), due to morphological embayment rotation. This meant that when compared to $\mathrm{E}-\mathrm{W}$ drift condition, the deflected rip flow in the W-E case had a greater alongshore component (correlation) than the E-W case (no correlation) where flow is deflected strongly offshore with minimal longshore component $(v)$.

\subsection{Drifter observations}

Eight drifter deployments were completed to complement the in-situ flow measurements to provide information on the spatial variation in the flow field around the groyne system. Table 2 provides summary data of the forcing, morphological and flow conditions during each drifter deployment. Deployments were collected under a variety of wave forcing conditions, including a range of offshore wave angles ( $\alpha$ ranging from $39^{\circ}$ west of shore-normal to $27^{\circ}$ east of shore-normal) and significant wave height $\left(H_{s}=0.4-1.1 \mathrm{~m}\right)$. Mean Lagrangian current velocities were calculated from all drifter observations taken during each c. 2-hour deployment and are likely to be lower than the maximum 10-min averaged Eulerian velocities measured at R1 and R2. Despite the temporal averaging, surprisingly strong offshoredirected velocities $(u)$ and resolved rip flow speeds $|u|\left(\sqrt{ }\left(u^{2}+v^{2}\right)\right)$ of up to $0.47 \mathrm{~m} \mathrm{~s}^{-1}$ and $0.71 \mathrm{~m} \mathrm{~s}^{-1}$ were measured, respectively. Surf zone widths were measured from the rectified timex video images and the mean surf zone width $\left(X_{b}\right)$ averaged over the drifter deployments ranged from 41 to $64 \mathrm{~m}$. A large proportion of released drifters exited the surf zone and maximum cross-shore flow deflection reached 70 $\mathrm{m}$ beyond groyne tip. The length of the groyne $\left(L_{g}\right)$ from the shoreline to the groyne tip ranged from 46 to $50 \mathrm{~m}$ and this variation was due to changes in wave height and (high tide) water level. The ratio of groyne length to surf zone width $\left(L_{g} / X_{b}\right)$ is an important factor controlling the surf zone flow dynamics associated with the groyne field, with values of $L_{g} / X_{b}>1$ indicating the surf zone is constrained within the groyne embayment. Measures for $L_{g} / X_{b}$ were between 0.9 and 1.3 during the experiment (Table 2).

Of the eight drifter deployments listed in Table 2, four specific deployments related to T2, T4, T11 and T12, were selected for further analysis. The mean flow pattern at $10 \mathrm{~m} \times 10 \mathrm{~m}$ grid resolution, derived from the drifter data for these deployments, are shown in Figure 7. During T2 and T4, predominantly wind waves approached from the west of shore-normal and generated eastward alongshore currents. During T2, the incident wave angle was $18^{\circ}$ and the offshore significant wave height was $0.7 \mathrm{~m}$ (Figure 5; Table 2). The eastward alongshore currents were moderately strong $\left(v=0.36 \mathrm{~m} \mathrm{~s}^{-1}\right)$ and deflected offshore around the groyne. The rip flow was strongest $\left(|\mathbf{u}|=0.51 \mathrm{~m} \mathrm{~s}^{-1}\right)$ near the tip of the groyne, where the offshore-directed flow exited the surf zone. The maximum offshore extent of the drifter tracks from the groyne tip was $40 \mathrm{~m}$ and the majority of drifters exited the surf zone without returning into the downdrift embayment. Drifters that passed very close to the groyne tip (within a few meters) had the greatest chance of re-entering the next embayment. A strong eastward alongshore flow was observed near the shoreline $\left(v=0.51 \mathrm{~m} \mathrm{~s}^{-1}\right)$, downdrift of the groyne, and no leeside cell circulation was observed. During $\mathrm{T} 4$, the wave angle was larger $\left(27^{\circ}\right)$, the offshore significant wave height was smaller $(0.5 \mathrm{~m})$ and the eastward alongshore current was rather weak $\left(v=0.28 \mathrm{~m} \mathrm{~s}^{-1}\right)$ (Figure 5; Table 2). This current was also then deflected at the groyne generating an offshore-directed rip flow, but the maximum flow speed in the rip $\left(|\mathbf{u}|=0.29 \mathrm{~m} \mathrm{~s}^{-1}\right)$ was significantly lower than observed during $\mathrm{T} 2$. The maximum-recorded offshore extent of the drifters during T4 was $30 \mathrm{~m}$ and, while many drifters exited the surf zone, a greater proportion of drifters remained in or re-entered the surf zone, with several drifters washing up in the downdrift embayment. In common with T2, no leeside cell circulation was observed.

In contrast to most of the drifter deployments, during the morning and evening tides on 8 October (T11 and T12) predominantly wind waves approached from the east of shore-normal and generated alongshore currents directed to the west. T11 represented the highest-energy drifter deployment with 
Table 2 - Summary statistics from drifter deployments. Deployments in grey (D2, D3, D6 and D7) represent T2, T4, T11 and T12, respectively.

\begin{tabular}{|c|c|c|c|c|c|c|c|c|}
\hline Drifter deployments & TO & T2 & T4 & T6 & T9 & T11 & T12 & T15 \\
\hline Date & $02 / 10$ & $03 / 10$ & $04 / 10$ & $05 / 10$ & 07/10 & $08 / 10$ & $08 / 10$ & $10 / 10$ \\
\hline Start (GMT) & 10:10 & 08:45 & 09:30 & 09:50 & $15: 14$ & 06:08 & $15: 04$ & $06: 25$ \\
\hline End (GMT) & $13: 38$ & $10: 56$ & $11: 58$ & $12: 42$ & $17: 15$ & 08:15 & $16: 42$ & $08: 34$ \\
\hline \multicolumn{9}{|l|}{ Environmental forcing } \\
\hline Wave height $\left(H_{s} ; \mathrm{m}\right)$ & 1.0 & 0.7 & 0.5 & 0.7 & 0.4 & 1.1 & 0.5 & 0.6 \\
\hline Wave period $\left(T_{z} ; \mathrm{s}\right)$ & 5.5 & 7.7 & 2.7 & 8.0 & 9.6 & 5.1 & 5.8 & 6.5 \\
\hline Wave direction $\left(D_{p} ;{ }^{\circ}\right)$ & 20.4 & 18.2 & 27.4 & 15.0 & -25.8 & -35.0 & -39.0 & -48.0 \\
\hline Offshore wind velocity $\left(\mathrm{m} \mathrm{s}^{-1}\right)$ & 3.6 & 1.4 & 0.4 & 0.8 & 1.7 & -2.2 & 3.2 & -0.7 \\
\hline Longshore wind velocity $\left(\mathrm{m} \mathrm{s}^{-1}\right)$ & 5.4 & 6.4 & 6.6 & 5.6 & -6.1 & -1.4 & -4.2 & -7.1 \\
\hline Wind speed $\left(\mathrm{m} \mathrm{s}^{-1}\right)$ & 6.6 & 6.6 & 6.7 & 5.7 & 6.5 & 2.6 & 5.3 & 7.2 \\
\hline Wind direction $\left({ }^{\circ}\right)$ & 61.0 & 81.9 & 90.7 & 85.6 & -69.2 & -142.0 & -48.1 & -90.4 \\
\hline High water level (m ODN) & 1.1 & 1.0 & 1.0 & 0.9 & 0.8 & 0.8 & 0.7 & 0.8 \\
\hline Mean water level (m ODN) & 0.9 & 1.0 & 1.0 & 0.9 & 0.8 & 0.8 & 0.6 & 0.8 \\
\hline Mean surf zone width $\left(X_{b} ; \mathrm{m}\right)$ & 62 & 55 & 41 & 63 & 47 & 64 & 49 & 49 \\
\hline \multicolumn{9}{|l|}{ Lagrangian flow statistics } \\
\hline Max. longshore velocity $\left(v_{\max } ; \mathrm{m} \mathrm{s}^{-1}\right)$ & 0.45 & 0.36 & 0.28 & 0.33 & 0.25 & 0.66 & 0.40 & 0.41 \\
\hline Max. offshore velocity $\left(u_{\max } ; \mathrm{m} \mathrm{s}^{-1}\right)$ & 0.42 & 0.24 & 0.14 & 0.20 & 0.14 & 0.47 & 0.25 & 0.24 \\
\hline $\begin{array}{l}\text { Max. speed }\left(|\boldsymbol{u}|_{\max } ; \mathrm{m} \mathrm{s}^{-1}\right) \\
\text { Cross-shore flow deflection beyond }\end{array}$ & 0.45 & 0.51 & 0.29 & 0.47 & 0.25 & 0.71 & 0.41 & 0.42 \\
\hline groyne tip (m) & 20 & 40 & 30 & 40 & 30 & 70 & 60 & 70 \\
\hline \multicolumn{9}{|l|}{ Groyne statistics } \\
\hline Groyne length $\left(L_{g} ; \mathrm{m}\right)$ & 49 & 49 & 49 & 50 & 46 & 48 & 49 & 47 \\
\hline Design groyne length $\left(L_{D} ; \mathrm{m}\right)$ & 70 & 70 & 70 & 70 & 70 & 70 & 70 & 70 \\
\hline$L_{g} / X_{b}(-)$ & 1.3 & 1.1 & 0.9 & 1.3 & 1.0 & 1.3 & 1.0 & 1.0 \\
\hline Groyne spacing $\left(L_{s} ; \mathrm{m}\right)$ & 225 & 225 & 225 & 225 & 225 & 225 & 225 & 225 \\
\hline$L_{s} / L_{g}(-)$ & 5.5 & 5.3 & 5.1 & 5.4 & 5.0 & 4.6 & 4.8 & 4.6 \\
\hline$L_{s} / L_{D}(-)$ & 3.2 & 3.2 & 3.2 & 3.2 & 3.2 & 3.2 & 3.2 & 3.2 \\
\hline Groyne tip depth (m ODN) & 0.95 & 0.95 & 0.95 & 0.95 & 0.95 & 0.95 & 0.95 & 0.95 \\
\hline Permeability (\%) & $0 \%$ & $0 \%$ & $0 \%$ & $0 \%$ & $0 \%$ & $0 \%$ & $0 \%$ & $0 \%$ \\
\hline Groyne angle $\left({ }^{\circ}\right)$ & 180 & 180 & 180 & 180 & 180 & 180 & 180 & 180 \\
\hline
\end{tabular}



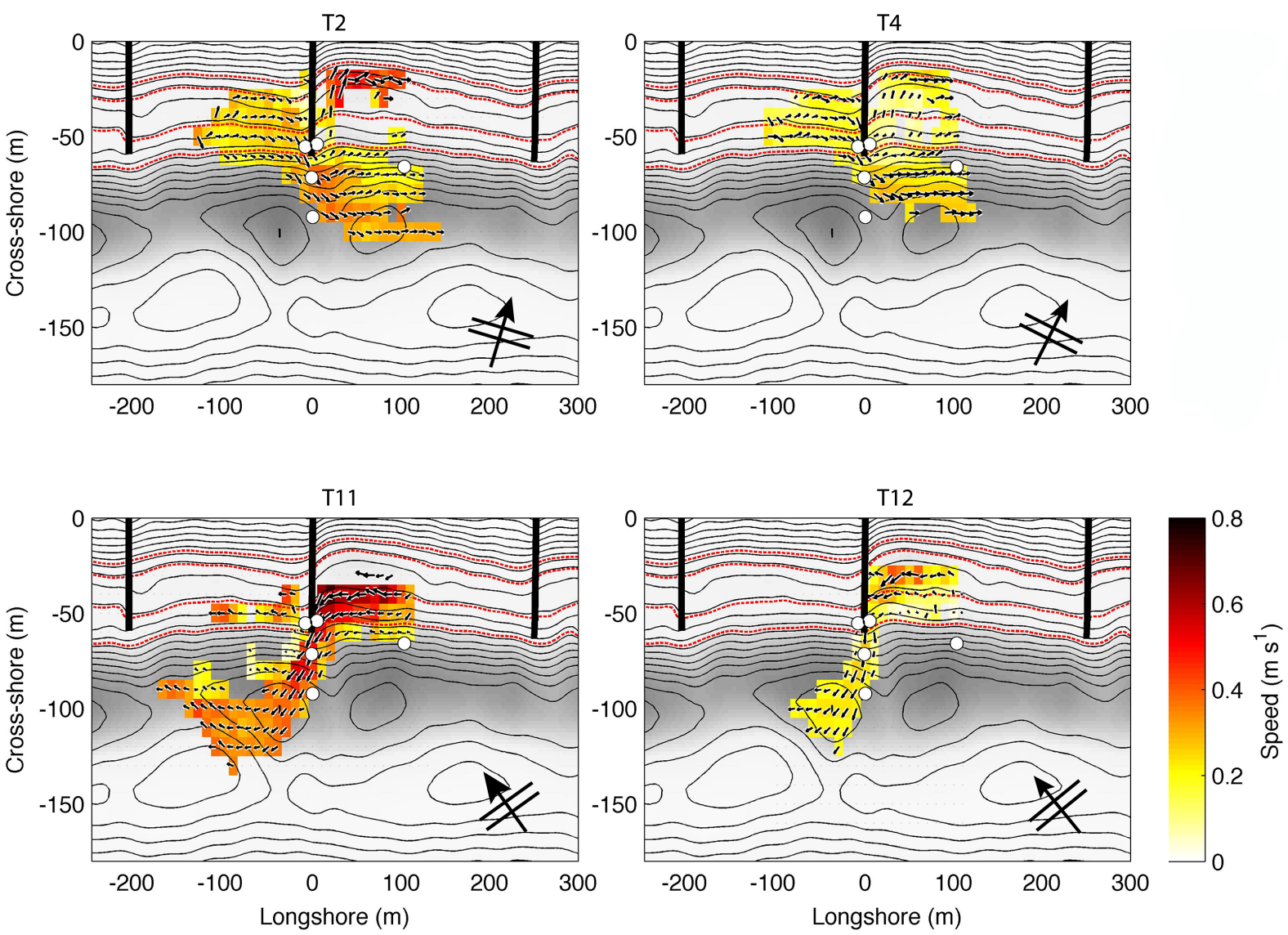

Figure 7 - Mean drifter velocity maps for T2 (3/10/2012), T4 (4/10/2012), T11 (8/10/2012 AM) and T12 (8/10/2012 PM). Contours are measured bathymetry at $0.25-\mathrm{m}$ intervals; grey shading represents linearly detrended residual morphology highlighting morphology of the low tide terrace, inner trough and outer bar (the residual morphology is derived from removing a $2 D$ linear trend surface from the inter-and sub-tidal morphology); red dashed lines are the mean tidal levels; and the filled white circles are rig positions (R1-R4 and P1; P2 is further offshore). Bold black arrow in bottom right indicates mean wave angle ( $\alpha$; arrow angle) and height ( $H_{s}$; arrow size).

an offshore significant wave height of $1.1 \mathrm{~m}$ arriving at a relatively large wave angle $\left(35^{\circ}\right)$ to the shorenormal and generating strong eastward alongshore currents (maximum $v=0.66 \mathrm{~m} \mathrm{~s}^{-1}$ ). Deflection of these alongshore currents offshore on the updrift side of the groyne generated strong offshore-directed rip flows with maximum velocities $\left(u=0.71 \mathrm{~m} \mathrm{~s}^{-1}\right)$ comparable to the strong Eulerian flows recorded by R2 $\left(u=1 \mathrm{~m} \mathrm{~s}^{-1}\right)$. T11 was the only drifter deployment during which leeside cell circulation was recorded by R1, which showed weak rip flows ( $u=0.2 \mathrm{~m} \mathrm{~s}^{-1}$; Figure 7) during the same event on the downdrift side of the groyne. These leeside rip flows were not observed in the drifter data. The majority of drifters in the rip exited the surf zone, reaching up to $70 \mathrm{~m}$ offshore of the groyne tip, until they reached the submerged outer bar location (no wave breaking over outer bar) when they turned alongshore down the coast to the west. Drifters that returned to the surf zone continued their westward movement and deflected offshore by the rip current associated with the next downdrift groyne. During T12, waves were also incident from the east under a large angle $\left(39^{\circ}\right)$, but were considerably less energetic with an offshore significant wave height of $0.5 \mathrm{~m}$ and relatively weak westward-directed alongshore currents (maximum $v=0.4 \mathrm{~m} \mathrm{~s}^{-1}$; Figure 5; Table 2). As observed in all drifter deployments, the alongshore currents were deflected offshore at the groyne, generating offshore directed rip flows $\left(|\mathbf{u}|=0.41 \mathrm{~m} \mathrm{~s}^{-1}\right)$. These exited the surf zone to an offshore extent of $60 \mathrm{~m}$. In contrast to T11, no leeside cell circulation was observed. 


\subsection{Factors controlling topographic rip flow}

The data from the in-situ instrument rigs and the drifter data strongly suggest that wave height and wave angle are the key factors that controls rip strength, with both larger wave angles and more energetic wave conditions resulting in stronger rip flows. To explore the relationship between wave forcing and boundary-controlled rip flow characteristics, a subset of instrument rig data was extracted from the data set comprising all offshore-directed rip velocity data $(u)$ from R1 and R2 for periods when either rig was updrift of the groyne (therefore representing the deflected rip current) as wave angle switched between east and west of shore normal associated with drift reversals. The subset of data thus obtained consists of 526 statistics of offshore significant wave height $\left(H_{s}\right)$, offshore wave angle ( $\alpha$; relative to the shoreline) and 10-min averaged rip flow velocity $(u)$, and is explored in Figure 8.

The flow velocities associated with the topographic rips are strongly correlated with both the offshore significant wave height and less so the incident wave angle (Figure 8; top two panels). Low wave heights $\left(H_{s}<0.5 \mathrm{~m}\right)$ and incidence angles $\left(\alpha<10^{\circ}\right)$ were associated with weak offshore-directed rip velocities $(u$ $<0.1 \mathrm{~m} \mathrm{~s}^{-1}$ ) at both R1 and R2 (eastward and westward alongshore currents). For larger waves and incidence angles, $u$ rapidly increased up to a maximum of $1 \mathrm{~m} \mathrm{~s}^{-1}$. One would expect $u$ to be correlated to some combination of $H_{s}$ and $\alpha$ through their control on the alongshore current velocity, and the strong and significant $(p<0.01)$ linear correlations between $u$ and $H_{s}$ and $u$ and $\alpha$ are, perhaps, somewhat surprising. However, a scatter plot of wave height versus wave angle (Figure 8; lower-left panel) indicates that in this case there is a correlation between $H_{s}$ and $\alpha$, and any of these two variables is therefore correlated to $u$. For westerly and easterly waves the maximum recorded rip velocities of $u=$ $0.63 \mathrm{~m} \mathrm{~s}^{-1}(\mathrm{R} 1)$ and $u=1 \mathrm{~m} \mathrm{~s}^{-1}$ (R2) were associated with wave angles $(\alpha)$ greater than $20^{\circ}$. For $\alpha<10^{\circ}$ topographic rips flows are weak at both rigs $\left(u<0.3 \mathrm{~m} \mathrm{~s}^{-1}\right)$ and strong topographic rip flows $\left(u>0.8 \mathrm{~m} \mathrm{~s}^{-1}\right)$ were only observed when $\alpha>30^{\circ}$.

The field data presented in Figure 6, and tabulated in Table 2, demonstrate that the strength of the longshore current measured in the groyne embayment is related to the strength of the deflected offshore-directed topographic rip flow. Figure 8 indicates that the latter is significantly correlated to the height of the waves and the incident wave angle. In Figure 8 we compare the force exerted on the nearshore region by the incoming waves (height and angle), by using the shear component of the radiation stress $\left(S_{x y}\right)$ which forces an alongshore current under oblique wave conditions (LonguetHiggins, 1970). $F_{y}$ is the longshore 'thrust' exerted by waves on water in the surf zone.

$F_{y}=\frac{1}{\rho} \frac{d S_{x y}}{d x}$

where

$\frac{d S_{x y}}{d x}=\frac{5}{4} \gamma^{2} \rho g h(\tan \beta \sin \alpha)$

where $\gamma=H / 2 h=0.4$ ( $h$ is depth at wave breaking), and slope $\tan \beta=0.06$. The relationship between $F_{y}$ and the squared offshore-directed topographic rip velocity $\left(u^{2}\right)$ for the combined R1/R2 data set demonstrates a strong linear correlation $(r=0.92)$ with a non-zero origin. Observed scatter associated with this relationship is primarily attributed to the morphological differences between the western (updrift over the long-term) and eastern (downdrift over the long-term) sides of the groyne, and the 

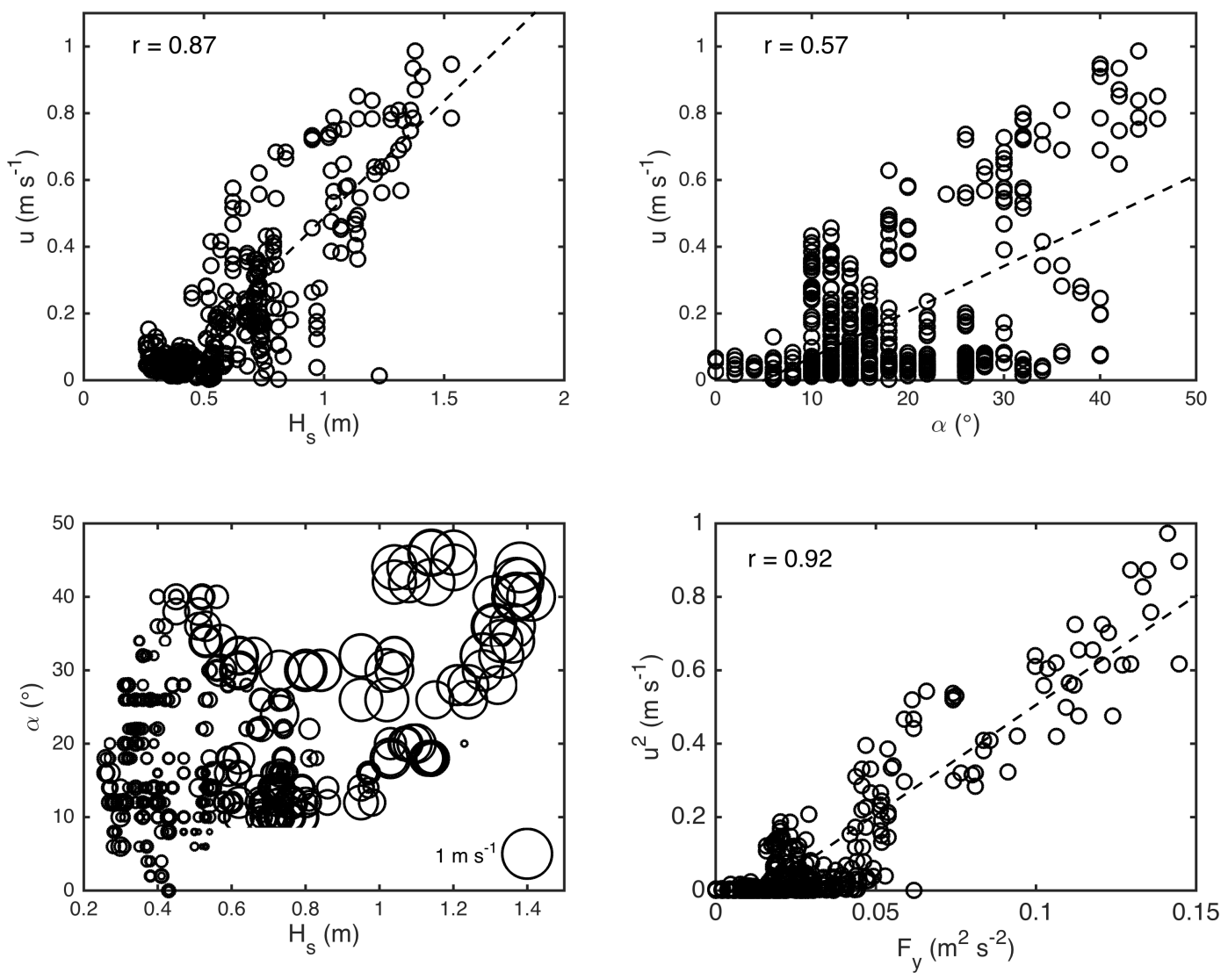

Figure 8-Top left: Measured offshore-directed 10-min averaged rip flow velocity (u), as a function of offshore significant wave height $\left(H_{s}\right)$. Top right: $u$ as a function of $\alpha$. Bottom left: $u$ scaled by symbol size, as a function of offshore significant wave height $\left(H_{s}\right)$ and wave angle to shore normal $(\alpha)$. Bottom right: $\mathrm{u}$ as a function of $\sqrt{H} \sin \alpha$, a parameterization representing the longshore component of wave forcing. Where present, dashed lines represent linear regression and are associated with corresponding correlation ( $r$ ) values.

difficulty in accurately representing the potential alongshore current strength with a bi-modal (swell and wind component) incoming directional wave spectrum.

In summary, the field data indicate that, in fetch-limited environments, forcing of boundary-controlled rip currents around a groyne structure can be primarily explained through the offshore deflection of alongshore-directed currents generated by obliquely-incident waves. Rip velocities are strongest on the updrift side of the groyne and were generally absent from the lee-side (down-drift). Measured offshoredirected rip flow velocities $\left(u^{2}\right)$ are strongly correlated $(r=0.92)$ to the longshore 'thrust' exerted by waves in the surf zone $\left(F_{y}\right)$ calculated with wave height $\left(H_{s}\right)$, and peak period angle to shore-normal $(\alpha)$.

\section{SCENARIO TESTING USING XBEACH}

The field measurements provided real-world observations of boundary-controlled rip behavior at Boscombe across a limited range of conditions and the use of scenario modeling with XBeach provides the opportunity to explore the fundamental forcing parameters that drive the rip dynamics across a larger $H_{s}-\alpha$ parameter space than was experienced during the field experiment. In addition, numerical modelling enables the investigation of the dependence of boundary-controlled rip flows to groyne geometry, thus providing insight into the applicability of the findings beyond Boscombe. 108 simulations of a range of scenarios were used to validate the performance of the model against observations and 
explore rip flow dynamics under a range of wave conditions and groyne configurations. An idealized alongshore-uniform bathymetry was used in the model simulations based on the recorded bathymetry (Figure 3). This removed the significance of updrift and downdrift differences in embayment morphology and provided a more direct test of structurally-driven hydrodynamics.

\subsection{Wave forcing and rip behavior}

Simulations of the flow field around a groyne system under a variety of values of $H_{s}$ and $\alpha$ were investigated. For all simulations, wave forcing was applied at the offshore boundary and a representative level of wind forcing was applied across the domain in the same direction as the wave approach. A following wind would be a very typical condition found in a fetch-limited environment where waves are mostly generated by local wind forcing. Simulations lasted 1.5 hours, but to avoid spool-up and initial transient effects, mean flow patterns were calculated over the period $t=30-60 \mathrm{~min}$. This set of computed flow fields were forced by 60 combinations of $H_{s}(0.25-1.5 \mathrm{~m})$ and $\alpha\left(0-45^{\circ}\right)$ that spanned the range of conditions observed during the observation period, but provided a better coverage of the $H_{s}-\alpha$ parameter space. These simulations were conducted with the same groyne dimensions as present at Boscombe.

Figure 9 shows the computed mean flow field around the groyne system for $H_{s}=0.5 \mathrm{~m}$ and $1 \mathrm{~m}$, and $\alpha=$ 0,15 and 45 degrees. Even though the simulations used simplified morphology, the flow patterns compare well qualitatively to the measured mean flow patterns from drifter runs with similar forcing conditions (cf. Figure 8). The salient features of the model simulations are: (1) flow speeds increase with increased wave height and wave angle up to $45^{\circ} ;(2)$ for the smaller wave conditions $\left(H_{s}=0.25-0.5 \mathrm{~m}\right)$ the deflected rip current flow clearly exits the surf zone (offshore current extends a considerable distance seaward of the surf zone), for the larger wave conditions $\left(H_{s}=1-1.5 \mathrm{~m}\right)$ the topographic rip is part of a meandering circulation with onshore currents downstream of the groyne; and (3) a downdrift (leeside) rip circulation develops under the larger wave heights $\left(H_{s}=1-1.5 \mathrm{~m}\right)$.
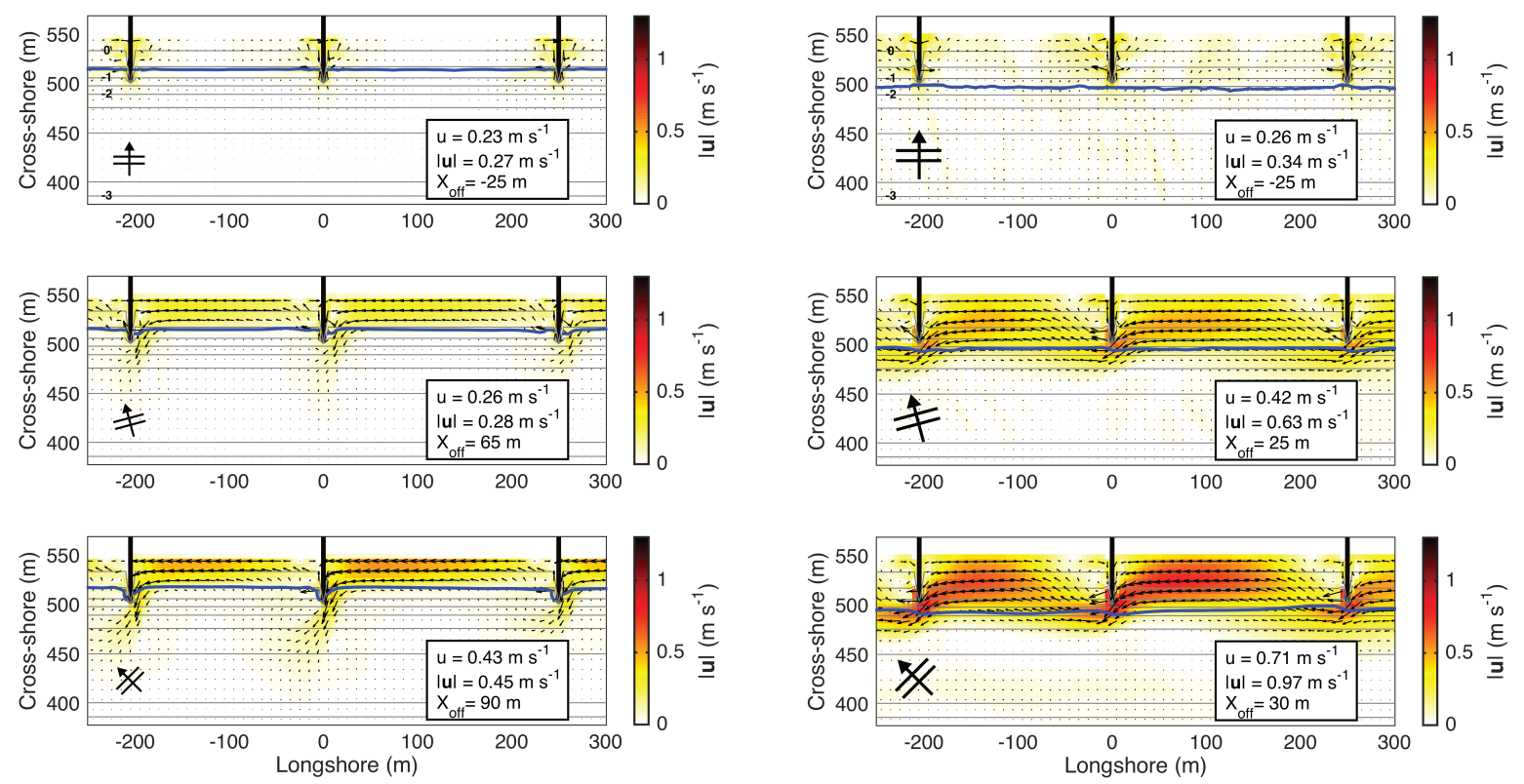

Figure 9-Computed mean flow patterns for $\mathrm{H}_{s}=0.5 \mathrm{~m}$ (left panels) and $1 \mathrm{~m}$ (right panels), and $\sigma=0^{\circ}$ (upper panels), $15^{\circ}$ (middle panels) and $45^{\circ}$ (lower panels). Vectors and shading show flow speed (|u|) and direction on a $5 \times 5 \mathrm{~m}$ grid. Black lines are impermeable groynes, and the blue line is the outer edge of the surf zone where computed wave dissipation is $10 \%$ of the cross-shore maximum. Flow statistics $\mathrm{u},|\mathrm{u}|$ and $X_{\text {off }}$ are included in each panel. 
Rip flow velocities for the upstream side of the groyne were extracted from the model data. As the simulations involved variable groyne dimensions, representative values for spatially- and temporallyaveraged offshore-directed rip velocity $(u)$ and resolved rip flow speed $(|\mathbf{u}|)$ where calculated as the maximum average velocities within an updrift region from the groyne that extended $0.1 L_{s}$ in the alongshore and $1.1 \mathrm{Lg}$ in the cross-shore from the shoreline. The modelled boundary-controlled rip flow speeds $(u)$ were compared to those observed during the experiment as a function of $H_{s}$ and $\alpha$ in Figure 10. Considering that the model simulations use simplified bathymetry and wave conditions, the simulated rip speeds compare reasonably well with observations where there is overlap with measured data. The model runs extend our understanding beyond the combinations of conditions that were observed during the experiment. The computed rip speeds, as expected, show that rip speed increases with increasing wave height and angle up to $45^{\circ}$, except for very small angles. Interestingly, the model results also indicate that as the wave height increases, so does the importance of wave angle for the resultant rip flow. During the largest simulated wave conditions $\left(H_{s}=1.5 \mathrm{~m}\right)$, a change in wave angle $(\alpha)$ from 0 to $15^{\circ}$ causes an increase in $|\mathbf{u}|$ from 0 to $0.58 \mathrm{~m} \mathrm{~s}^{-1}$. Model results also support the field observation that at low wave heights $\left(H_{s}<0.4 \mathrm{~m}\right)$ the variation in wave angle has little effect on rip flow speed. In fact, when $\alpha$ increases from 0 to $45^{\circ}$ for $H_{s}=0.25 \mathrm{~m},|\mathrm{u}|$ only increases from 0.16 to $0.27 \mathrm{~m} \mathrm{~s}^{-1}$. As expected, the strongest rip flows $\left(|\mathbf{u}|=0.92 \mathrm{~m} \mathrm{~s}^{-1}\right)$ occur under the largest waves at $45^{\circ}$ angle from shore-normal $\left(H_{s}=1.5 \mathrm{~m} ; \alpha=45^{\circ}\right)$. No boundary-controlled rip flow occurs when waves are shorenormal, regardless of the same wave height.

When the rip flow speeds $\left(u^{2}\right)$ were examined as a function of $F_{y}$, a highly significant correlation was found ( $r=0.99$; Figure 10). The rip flow response to oblique wave forcing in both the idealized simulation and measured dataset compare well and reinforce the positive linear relationship found in the observed data. In the simulated case, the scatter found when $u^{2}<0.1$ can be due to the breakdown in the relationship between rip flow $u$, and $F_{y}$ at low wave heights $\left(H_{s}<0.4\right)$. The deviation in some values for $u^{2}$ in the measured data above $F_{y}=0.04$ could be due the result of morphological differences, but linear regressions compare well considering simulations are idealized.

\subsection{Effect of groyne configuration}

The properties of the groyne have been kept constant during the simulations discussed in the previous section, but are of importance to the generation of boundary-controlled rips flows. The three key groyne properties are length, spacing and permeability; in this section the influence of groyne length and spacing on deflected topographic rip flows are investigated. The permeability of a groyne structure is also important, as a more permeable groyne will present less of an obstruction to the flow (e.g., Van Rijn, 2011). However, for the purpose of this contribution, the focus is on fully impermeable groynes that will present maximum flow modification and present the greatest rip current hazard to bathers.

Groyne length is a key control on the offshore extent of the deflected rip current with longer groynes associated with a larger offshore deflection of the current. The offshore extent of deflected rip flow ( $X_{\text {off }}$ ) in the simulations was expressed as the distance from the groyne tip to point at which the offshore directed flow velocity dropped below $0.03 \mathrm{~m} \mathrm{~s}^{-1}$. It is the ratio between groyne length and surf zone width $L_{g} / X_{b}$ that is of most importance, and both the field measurements (Figure 7; Table 2) and the previous simulations (Figure 9) already provided clear insight that for smaller waves $\left(L_{g} / X_{b}>1\right)$ the deflection of the topographic rip $\left(X_{\text {off }}\right)$ is relatively large, whereas for larger waves $\left(L_{g} / X_{b}>1\right)$ the surf zone extended beyond the groyne tip and the topographic rip flow was characterised by a more meandering circulation pattern with limited offshore extent. In the field, a change in wave conditions automatically induced a change in $L_{g} / X_{b}$, and it is difficult to separate the effects of variable $H_{s}$ and $L_{g} / X_{b}$. 

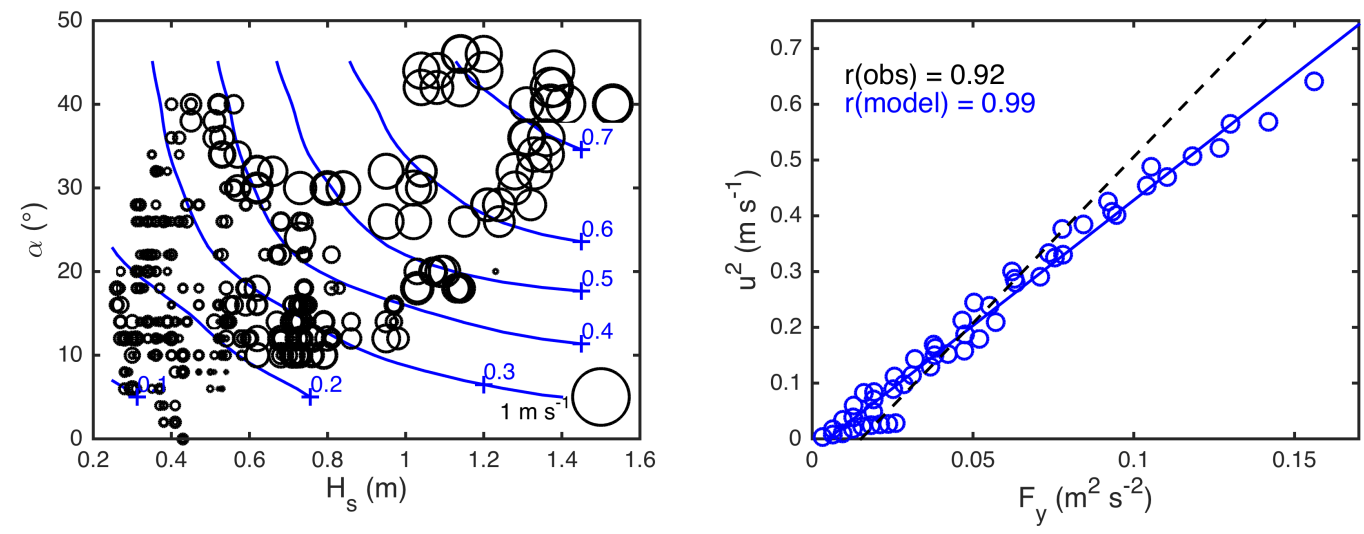

Figure 10 - Left panel shows scatter plot offshore-directed rip flow speed $(u)$ as a function of significant wave height $\left(H_{s}\right)$ and wave angle $(\alpha)$, where observed $R 1$ and $R 2$ combined are scaled open circles and model simulations are blue contours. Right panel shows offshore-directed 10-min rip flow speeds (u) as a function of a parameterization of the alongshore thrust by waves. The linear least-squares fit and correlation coefficient for observed and model data are shown by the black and blue dashed lines, respectively.

XBeach was therefore used to simulate topographic rip flows for constant wave conditions, but variable groyne length. The wave condition for the 48 simulations was fixed at $H_{s}=1 \mathrm{~m}$ and $\alpha=45^{\circ}$, which resulted in a fixed surf zone width of $55 \mathrm{~m}$. Simulations were then run for effective groyne lengths $L_{g}=0$ -125 (approx. $15 \mathrm{~m}$ intervals), giving groyne length to surf zone width ratios of $L_{g} / X_{b}=0-2.8$.

The results show that the maximum rip flow speed $(|\mathbf{u}|)$ is strongest in the short groyne scenarios $\left(L_{g} / X_{b}\right.$ $<1$ ), with $|\mathbf{u}|=1.13 \mathrm{~m} \mathrm{~s}^{-1}$ at $L_{g} / X_{b}=0.6$ (Figure 11). The rip flow extends $25 \mathrm{~m}$ from the groyne tip, $5 \mathrm{~m}$ beyond the surf zone extent $\left(X_{b}=55 \mathrm{~m}\right)$, with the rip flow mostly contained within the surf zone. In this case the groyne acts to compress, but not break-up the alongshore current. A meandering alongshoredirected current occurs under such conditions. For the intermediate groyne length $\left(L_{g} / X_{b}=0.9\right)$, the offshore deflection of the rip flow reaches $30 \mathrm{~m}$ from the groyne tip, which is $25 \mathrm{~m}$ beyond the surf zone, with a maximum deflected rip flow speed of $|\mathbf{u}|=1.07 \mathrm{~m} \mathrm{~s}^{-1}$. The flow field indicates that the alongshore current is partially detached with some of the flow returning landward downstream of the groyne. Finally, in the long groyne scenario $\left(L_{g} / X_{b}=1.2\right)$, significant deflection of flow occurs the surf zone flow pattern. The groyne fully blocks the alongshore current, which is almost entirely deflected offshore with little downstream recirculation to landward. The offshore extent of the flow from groyne tip is $80 \mathrm{~m}, 90$ $\mathrm{m}$ beyond the surf zone and the maximum deflected rip flow speed is $|\mathbf{u}|=0.89 \mathrm{~m} \mathrm{~s}^{-1}$. This scenario has the lowest rip speed, but the furthest offshore extent.

The spacing between groynes controls the size of the embayments, which represents the distance over which the alongshore current develops in addition to any alongshore momentum transferred from the upstream embayment (tip bypassing at low $L_{g} / X_{b}$ ). At the upstream end of the embayment (just downstream from the groyne) there is a shadow zone where wave height is reduced. Beyond the shadow zone, obliquely incident breaking waves generate an alongshore-directed current that reaches its maximum at the downstream end of the embayment (just upstream from the groyne). Increasing the groyne spacing would increase the distance over which the alongshore current can develop within each embayment and stronger flow velocities could be expected. Figure 12 shows examples of computed flow patterns for $H_{s}=1 \mathrm{~m}, \alpha=45^{\circ}, L_{g}=50 \mathrm{~m}, X_{b}=55 \mathrm{~m}$ and $L_{g} / X_{b}=0.9$, and for groyne spacing $L_{s} / L_{g}$ ranging from 2 to 8 (simulations were run for $L_{s} / L_{g}=0.6-9.2$ ). The results show that increasing the groyne spacing increases the alongshore current flow and hence the flow speed of the deflected topographic rip current. In Figure 12 the topographic rip flow speed $(|\mathbf{u}|)$ increase significantly when $L_{s} / L_{g}$ increases from 2 to 4 , whereas $|\mathbf{u}|$ for $L_{s} / L_{g}=4$ and 8 are quite similar. This would suggest that, for the simulated wave 

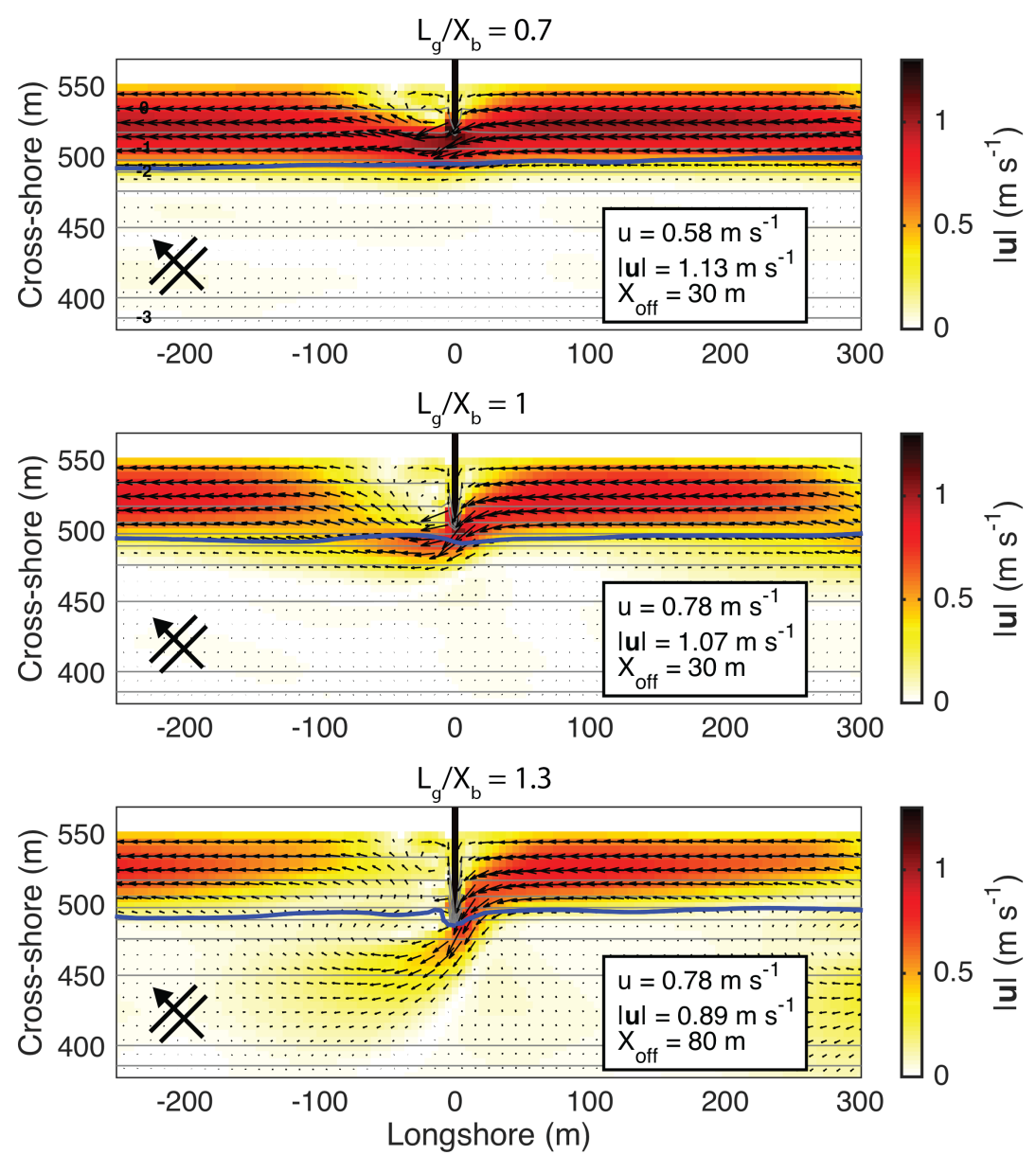

Figure 11 - Computed mean flow patterns for $H_{s}=1 \mathrm{~m}$ and $\alpha=45^{\circ}$, and for $L_{g}=35 \mathrm{~m}$ (top panels), $50 \mathrm{~m}$ (middle panel) and $65 \mathrm{~m}$ (lower panel). Vectors and shading show flow speed $(|\mathbf{u}|)$ and direction on a $5 \times 5 \mathrm{~m}$ grid. Black lines are impermeable groynes, the blue line is the outer edge of the surf zone where computed wave dissipation is $10 \%$ of the cross-shore maximum. Flow statistics and wave conditions are included in each panel.

conditions at least, the alongshore current was near full development for $L_{s} / L_{g}=4$ and increasing the groyne spacing even more has limited effect.

The model simulations with constant wave conditions, but varying groyne geometry, provides new insights into rip current hazards around groynes (Figure 13). The findings illustrate that the ratio between groyne length and surf zone width $L_{g} / X_{b}$ controls the offshore extent of the deflected topographic rip current $X_{\text {off, }}$, whereas the ratio between groyne spacing and groyne length $L_{s} / L_{g}$ provides the principal structural control on the deflected rip flow speed $|\mathbf{u}|$. When the groyne extends beyond the surf zone $\left(L_{g} / X_{b}>1\right)$, the offshore deflection of the alongshore current and the seaward extent of the offshore-directed topographic rip current rip flow progressively increases with $L_{g} / X_{b}$. The increase in offshore deflection is accompanied by a modest reduction in the topographic rip flow speed. If, on the other hand, the groyne resides within the surf zone $\left(L_{g} / X_{b}<1\right)$, the offshore deflection of the alongshore current and the development of an offshore-directed topographic rip current is limited. The relatively strong and compressed current around the tip of the groyne forms a meandering alongshore current and does not extend significantly seaward of the surf zone. Model simulations indicate that the flow speed at the groyne tip is maximum when $L_{g} / X_{b}=0.6$ and reduces towards the unconstrained alongshore current speed as $L_{g} / X_{b}$ approaches zero. 

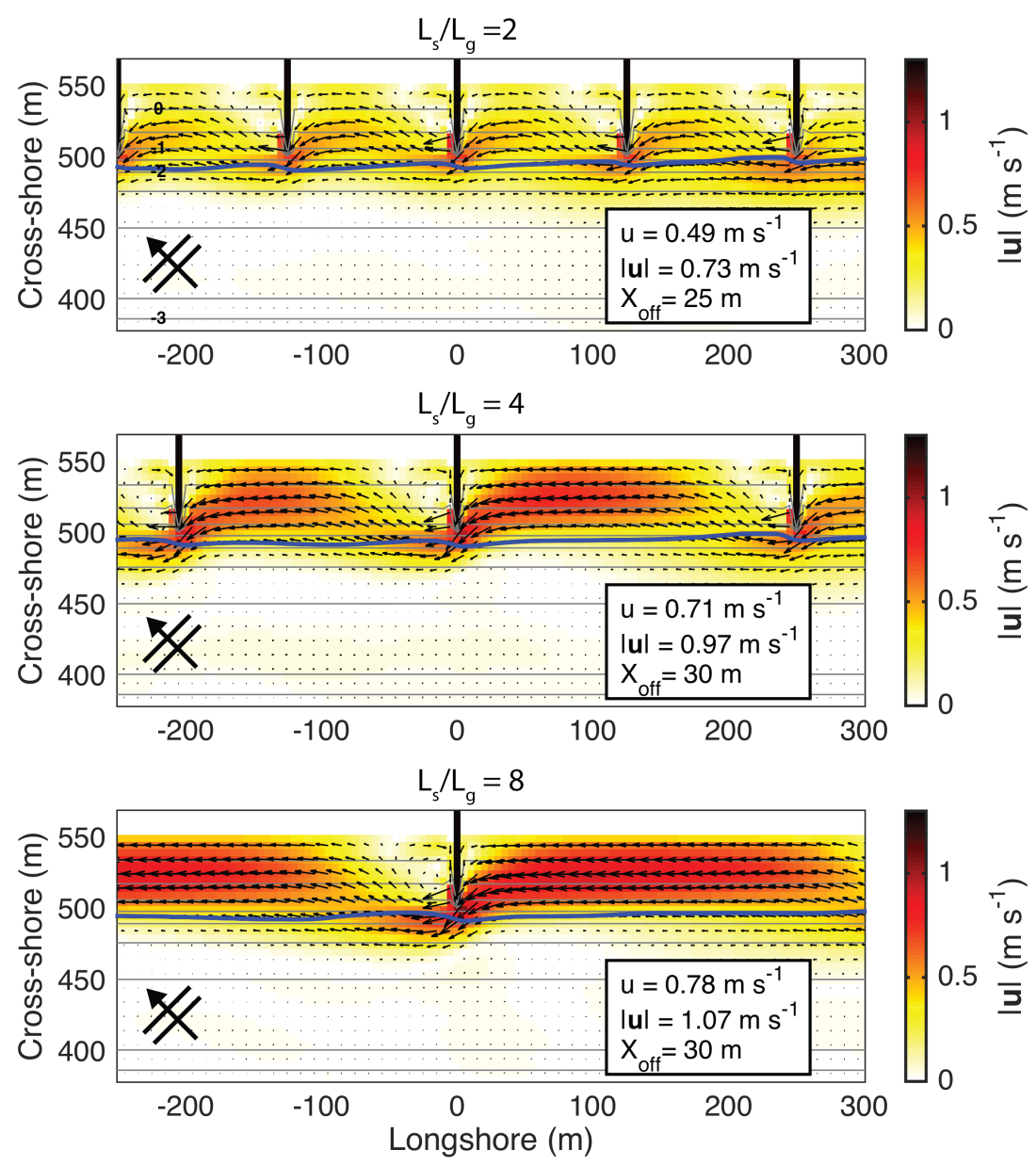

Figure 12 - Computed mean flow patterns for $H_{s}=1 \mathrm{~m}$ and $\alpha=45^{\circ}$, and for $L_{g} / L_{g}=2$ (top panels), $L_{g} / L_{g}=4$ (middle panel) and $L_{g} / L_{g}=8$ (lower panel). Vectors and shading show flow speed $(|\mathbf{u}|)$ and direction on a $5 \times 5 \mathrm{~m}$ grid. Black lines are impermeable groynes, the blue line is the outer edge of the surf zone where computed wave dissipation is $10 \%$ of the cross-shore maximum. Flow statistics and wave conditions are included in each panel.

It is worth emphasizing that $L_{g}$ is fixed for any specific field site, but that the effective groyne length is modulated by the tide and that $X_{b}$ depends on the wave conditions; therefore $L_{g} / X_{b}$ varies both with tide and wave conditions, even though the physical length of a groyne remains constant. Significantly for bathing hazards, the results indicate that the pronounced topographic rip flows, i.e., those with the large seaward extent, can actually occur under relatively calm wave conditions. When the groynes are closely spaced $\left(L_{s} / L_{g}<4\right)$, there is not sufficient embayment length to build up strong alongshore currents and, accordingly, the topographic rip flows are relatively weak. When the groynes are widely spaced $\left(L_{s} / L_{g}>\right.$ 6), alongshore currents attain their maximum speed within the large embayments and topographic rip flows are also maximised. Increasing $L_{s} / L_{g}$ much beyond a value of 6 does not result in further increases in the topographic rip flow velocities. Design criteria for groynes on sandy beaches vary depending on application, but include recommended values of $L_{g} / X_{b}<1$ for storm conditions and $L_{g} / X_{b}>1$ under modal conditions (to allow some sediment bypassing during storms), and $L_{s} / L_{g}=1.5-3$ (Kana et al., 2004; Basco and Pope, 2004; Özölçer et al., 2006, Van Rijn, 2013). Critically, these geometries promote the development of strong offshore-deflected boundary-controlled rip currents that extend a significant distance offshore, leading to scenarios of high bathing hazard. 


\section{DISCUSSION AND CONCLUSIONS}

Field measurements from Boscombe beach clearly demonstrate that strong boundary-controlled rip flows exist in association with groynes, and that the development of these currents in a fetch-limited environment is principally related to the deflection of the alongshore current by the coastal structure. The flow dynamics are strongly driven by the significant wave height $H_{s}$ and incident wave angle $\alpha$. The field data were collected within a relatively limited $H_{s}-\alpha$ parameter space and fixed groyne length $L_{g}$ and groyne spacing $L_{s}$. The XBeach numerical model was shown to reproduce the Eulerian and Lagrangian field data very well, and was subsequently used to extend the parameter space of the forcing (wave conditions) and controlling (groyne configuration) parameters to enhance our understanding of boundary-controlled rip currents. In addition to confirming the importance of wave height and incident wave angle in driving boundary-controlled rip currents, the modelling also highlighted the importance of the groyne configuration, especially the ratio between groyne length to surf zone width $\left(L_{g} / X_{b}\right)$. However, it is difficult to separate out the effects of wave conditions and groyne configuration; for example, larger waves result in an increased surf zone width, and hence reduce $L_{g} / X_{b}$.

Figure 14 summarizes both the effect of wave forcing and the groyne configuration on the topographic rip flow characteristics as simulated using XBeach. The upper two panels show contour plots of the simulated Lagrangian topographic rip speed $|\mathbf{u}|$ and velocity $u$ as a function of $H_{s}$ and $\alpha$, from the simulations distributed across the $H_{s}-\alpha$ parameter space $\left(H_{s}=0.25-1.5 \mathrm{~m} ; \alpha=0-45^{\circ}\right)$, with Boscombe groyne configuration. From a beach safety perspective, rip flow speeds $(|\mathbf{u}|)$ become a potential hazard to bathers above about $0.3 \mathrm{~m} \mathrm{~s}^{-1}$ (McCarroll et al., 2015) and model simulations in Figure 14 support field data in indicating that thresholds exist at $H_{s} \approx 0.4 \mathrm{~m}$ and $\alpha \approx 10^{\circ}$ below which the hazardous offshoredirected component $(u)$ of rip flow remains below $0.3 \mathrm{~m} \mathrm{~s}^{-1}$. Interestingly, when $H_{s}>1 \mathrm{~m}$, rip flows are very sensitive to wave angle. For $0.4<H_{s}<1 \mathrm{~m}|\mathbf{u}|$ and $u$ become more $H_{s}$-limited above $\alpha=20^{\circ}$.

Rip current bathing hazard is considered a function of both the potential to exit the surf zone (related to offshore deflection) and the offshore-directed rip flow speed (Scott et al., 2014). The lower left panel of Figure 14 illustrates the relationship between topographic rip flow speed and offshore flow deflection $\left(X_{o f f}\right)$ as a function of relative groyne length (for $L_{s}=275 \mathrm{~m} ; H_{s}=1 \mathrm{~m} ; \alpha=45^{\circ}$ ), as conceptualized in Figure 13. This example clearly shows three clear behavioural phases, 1 ) where $0<L_{g} / X_{b}<0.5$, no significant offshore deflection occurs and $|\mathbf{u}|$ is close to the natural alongshore current velocity; 2 ) increasing groyne length to $0.5<L_{g} / X_{b}<1.25,|\mathbf{u}|$ is maximized as alongshore flow is compressed within the surf zone, offshore deflection increases but typically remains part of meandering alongshore current; and 3 ) when $L_{g} / X_{b}>1.25$ offshore deflection rapidly increases and $|\mathbf{u}|$ decreases to a quasi-constant speed as flow is fully deflected and no momentum is exchanged between embayments. Under these simulated conditions bathing hazard dramatically increases once $L_{g} / X_{b}>0.5$ with strongest rip flow hazards occurring before the rip flow becomes fully deflected, then with the highest rip exit hazard $\left(X_{\text {off }}=141 \mathrm{~m}\right)$ occurring in combination with moderately high flow hazard $\left(|\mathbf{u}|=0.68 \mathrm{~m} \mathrm{~s}^{-1}\right)$ at $L_{g} / X_{b}=2.3$.

Groyne design criteria recommend a maximum groyne spacing of $L_{s} / L_{g}=3$ (Özölçer et al.,2006; Van Rijn, 2013) beyond which the development of the alongshore current increases erosion. Özölçer et al.,2006 reported maximum accreationary performance of T-shaped groynes occurring at $L_{g} / X_{b}=2$ based on physical model experiments. The lower right panel of Figure 14 shows the simulated relationship between $L_{s} / L_{g}$ and $|u|$ for both data points where $0.5<L_{g} / X_{b}<1.25$ and $L_{g} / X_{b}>1.25$. Long groyne scenarios showed a increasing rip flow $(|u|)$ up to $L_{s} / L_{g}>4$, constraints due to model domain size meant long groyne length could not be fully tested beyond this. One would expect, based on earlier evidence, that flows for long groyne scenarios would become asymptotic towards the fully developed alongshore current velocity (shown in Figure 14) at $L_{s} / L_{g}=4-6$. For the short groyne cases, flow continues to increase. 


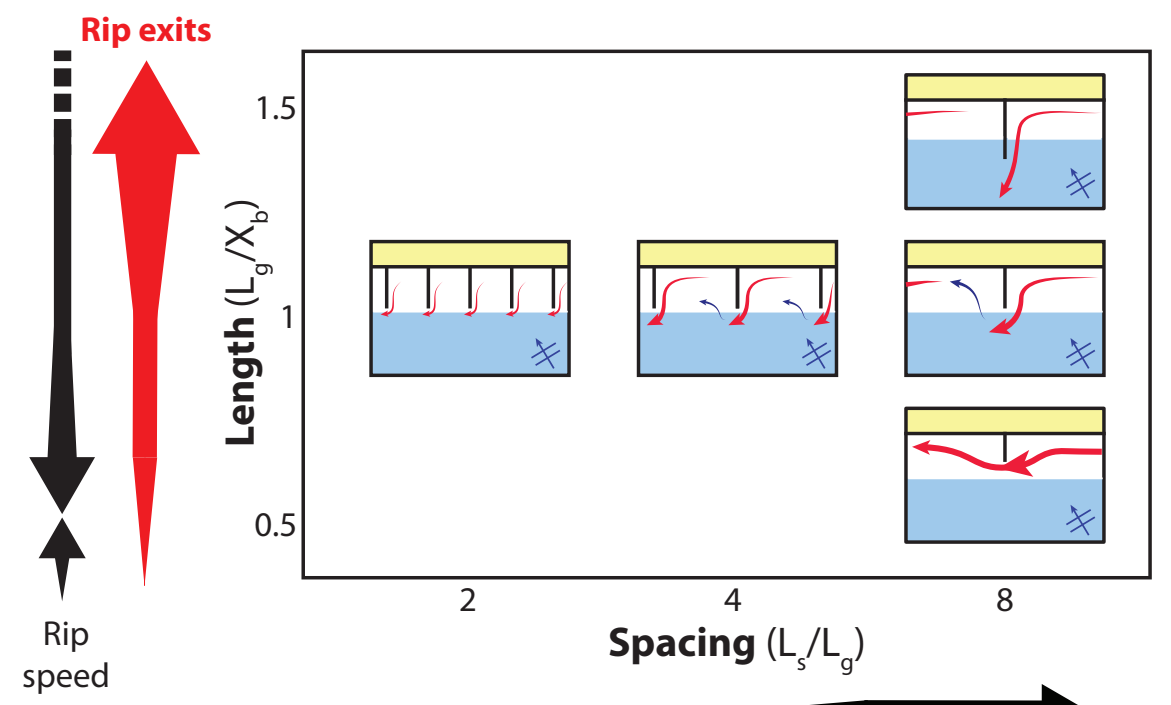

Rip speed

Rip exits

Figure 13 - Summary of model simulations to evaluate structural control on topographic rip flow around a groyne field as a function of groyne spacing $L_{s}$, groyne length $L_{g}$ and surf zone width $X_{b}$. Wave conditions are fixed at $H_{s}=1 \mathrm{~m}$ and $\alpha=45^{\circ}$. Simulations are valid for Boscombe bathymetry.

beyond this due to flow compression within a meandering alongshore current, where a fully developed situation appears to occur around $L_{s} / L_{g}=6$. Therefore simulations for the simplified Boscombe morphology, at $H_{s}=1 \mathrm{~m}$ and $\alpha=45^{\circ}$, suggest that rip flow linearly increases above $L_{s} / L_{g}=1$ until reaching a fully developed state at $L_{s} / L_{g}=4-6$.

Beyond the static bathing hazard levels associated with rip flow and its offshore extent due to the incoming wave field and groyne geometries, the field data collected at Boscombe has indicated the importance of considering the temporal variation of boundary-controlled rip flow characteristics, particularly in association with drift reversal and rapid changes in wave height. These scenarios can all affect the effective groyne length $\left(L_{g} / X_{b}\right)$ and induce rapid fluctuations in $|\mathbf{u}|$ and $X_{\text {off }}$ when oscillating around $L_{g} / X_{b}=1$. With drift reversals, subtle differences in morphology on either side of the groyne, where a dominant drift direction exists, mean that alongshore flow reversals typically activate the more eroded leeside (under dominant conditions) of the groyne embayment leading to an increase in $L_{g} / X_{b}$ and rip flows exiting the surf zone. This is highlighted in Figure 6, where offshore-directed flows that developed on the easterly (leeside) of the groyne after a drift reversal buried R4 with sand highlighting the potential for significant offshore sediment transport and morphological change under these conditons. Indeed, this affect also occurs in the field and model data under decreasing wave energy from a constant angle, where surf zone width decreases, increasing $L_{g} / X_{b}$. Finally, untested in this study but clearly observed in the field is the effect of tidal level on effective groyne length. A Boscombe, under spring tide conditions, the shoreline extended beyond the groyne tip at low water and $L_{g} / X_{b}>1$ under low-moderate wave conditions.

The greatest significance of this study is for fetch-limited wind-wave environments with groynes, where the directional wave climate is often bi-modal and where our field data has shown that boundarycontrolled rip flows can be equal or greater than those in open beach rip currents under much less 
energetic conditions. In the interest of extrapolating these findings beyond the studied environment, some important similarities are seen in field and modeling studies of larger-scale swell-dominated headland-controlled rip systems, investigating the transport of floating material between the surf zone and inner shelf through topographic rip flows on embayed beaches (Castelle and Coco, 2013; McCarroll et al., 2014). In particular, the studies of Castelle and Coco (2013) exploring headland effects on embayed beaches (where $L_{g} / X_{b} \gg 1$ ) reinforced the importance and efficiency of deflected boundarycontrolled rip currents as a conduit for transporting floating material beyond the surf zone. Their simulation showed that headland-controlled rips had a greater exit rate than measured in unconstrained beach rip currents. One significant difference in our field data was the relative lack of observation of leeside rip current circulation. Recent field and modeling studies by Pattiaratchi et al., (2009) and Castelle and Coco (2013) measured and simulated significant leeside rip current eddies that develop in the wave shadow zone under oblique swell-wave approach. In strongly embayed cases $\left(L_{s} / L_{g}<1\right)$ Castelle and Coco (2013) found that these leeside circulations dominated surf zone circulation and were the primary conduit for offshore transport beyond the surf zone. The relatively short groyne length and less energetic short-period wind seas in the Boscombe case limit the potential for leeside 'shadow' rip development.

In addition to the structural modification of flows discussed, considerations must be made for a range of important site-specific factors which all represent important areas for further study:

- Local bathymetry can significantly modify offshore waves before breaking. For example, the steepness of the cross-shore profile can have a significant impact upon, breaker angle and surf zone width.

- The movement of the tide in some areas will have a significant effect on topographic rip behaviour. Key rip parameters like the groyne length $\left(L_{g}\right)$, surf zone width $\left(X_{b}\right)$, wave height $\left(H_{s}\right)$ and wave angle $(\alpha)$ can be affected by the mean water level. For example, in some UK locations, particularly when groynes are designed to protect a steep upper beach fronted by a wide lowtide terrace, it is common for the low tide shoreline to drop past the groyne tip altogether, leaving the structure periodically dry.

- Daily tidal movement can also create tidal currents that flow along the coast. In some cases these currents can have a significant influence within the nearshore zone, creating a periodic ( $6 \mathrm{hr}$ ) alongshore-directed current that, although typically weak, may modify wave-driven alongshore flows.

- Finally, it is important to consider the impact the groyne system or geological feature has on beach morphology. By modifying the waves and currents, in turn the beach morphology will be affected just like any other dynamic beach system. Therefore consideration of the natural beach type is important when assessing potential rip activity. The morphodynamic impact of groynes on intermediate beach types (e.g. Low-tide terrace) can be important in the development and 'fixing' of permanent beach rips both adjacent to and seaward of the groyne tip. These rip system may have characteristics more similar to beach or boundary-controlled rips depending on the direct hydrodynamic impact of the structure on the flow. At the other end of the scale, in a case where groynes or obstructions occur on a reflective beach, the rip flow will be controlled directly by the hydrodynamic impact of the structure(s).

Understandably, previous research on beach groynes and coastal structures has been mainly focused on their intended role as coastal protection schemes. This study has attempted to highlight the lack of understanding, and specifically field observations, of the impact that coastal structures in the surf zone have on rip current dynamics. In this case, the rationale relates to beach safety management, but it is becoming increasingly clear that structurally-controlled boundary rip currents of all scales (both manmade and geological) have the potential to transport significant amounts of floating material and 
sediment beyond the surf zone. This has significant implications for coastal hazards, particularly beach safety as well as beach erosion during storm conditions, and represents a significant knowledge gap that needs addressing in future research.
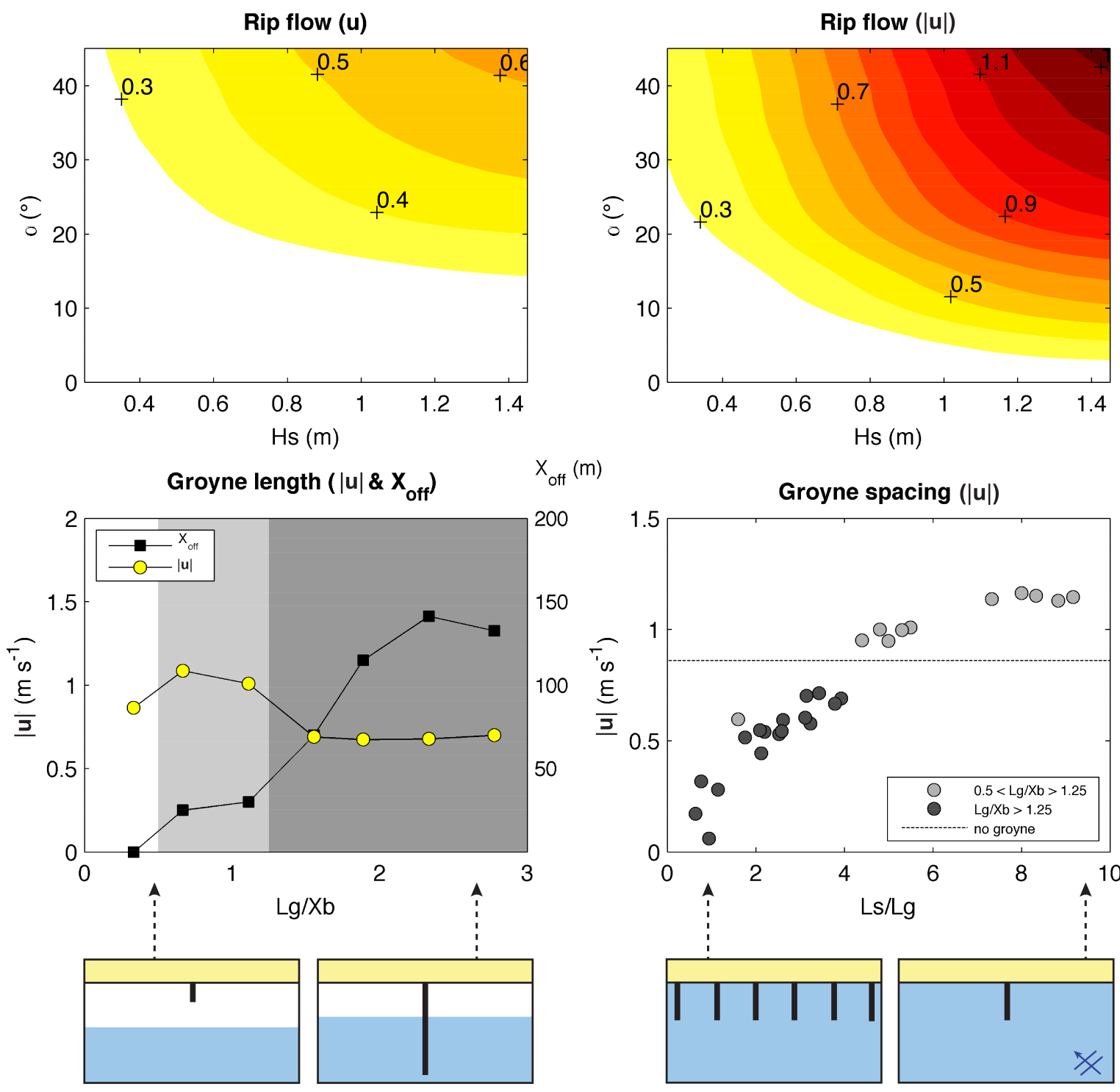

$\mathrm{X}_{\text {off }}(\mathrm{m})$

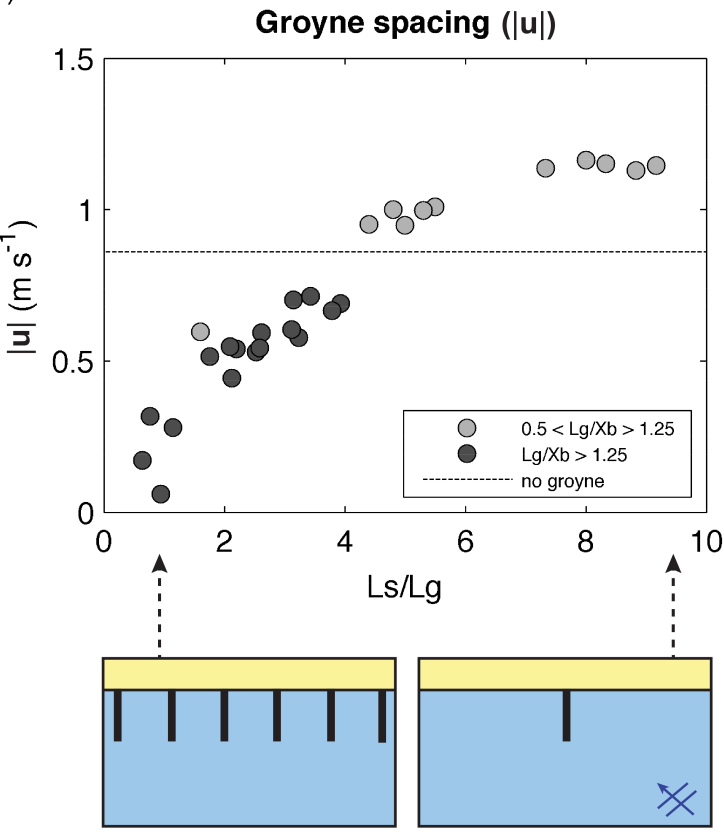

Figure 14 - Upper panels show contour plots of the simulated topographic rip current Lagrangian velocity $u$ and rip speed |u| as a function of $H_{s}$ and $a$. The lower left panel illustrates the relationship between topographic rip flow speed and offshore flow deflection as a function of relative groyne length. The lower right panel shows the simulated relationship between $L_{s} / L_{g}$ and $|\mathbf{u}|$ for data points where $0.5<L_{g} / X_{b}<1.25$ and $L_{g} / X_{b}>1.25$. Supporting diagrams graphically illustrate the associated groyne configuration. 


\section{ACKNOWLEDGEMENTS}

We would like to thank our excellent field and technical team: Peter Ganderton, Anthony Thorpe, Claire Earlie, Ellie Woodward, Tim Poate, Megan Sheriden, Pedro Almeida and Robert McCall. We would also like to thank the project partners and collaborators, the RNLI, the Met Office and HEIF V, for providing financial, logistical and data support during the project. Matthew Lloyd from Bournemouth City Council is also thanked for his logistical support in the field.

\section{REFERENCES}

Austin, M. J., Scott, T., Masselink, G. and Russell, P.E. (2012). Rip Current Prediction: development, validation and evaluation of an operational tool. Journal of Coastal Research, 29(2), 283-300.

Austin M. J., Masselink G., Scott T., Russell P. E. (2014). Water-level controls on macro-tidal rip currents. Continental Shelf Research, 75, $28-40$.

Basco, D.R. and Pope, J. (2004). Groin functional design guidance from the coastal engineering manual. Journal of Coastal Research, SI 33, 121-130.

Bowen, A. J. and Inman, D. L. (1969). Rip currents 2. Laboratory and field observations. Journal of Geophysical Research, 74(23), 5479-5490.

Castelle, B. and Coco, G. (2013). Surf zone flushing on embayed beaches. Geophysical Research Letters, 40.

Gourlay, M.R. (1974). Wave set-up and wave generated currents in the lee of a breakwater or headland. In: Coastal Engineering 1974: Proceedings of the Fourteenth International Conference. American Society of Civil Engineers, New York, $1976-1995$.

Kana, T.W., White, T.E. McKee, P.A. (2004). Management and engineering guidelines from groin rehabilitation. Journal of Coastal Research, SI 33, p. 57-82.

Komar, P.D. (1979). Beach slope dependence of longshore currents. Journal of Waterway, Port, Coastal and Ocean Division, ASCE, Vol. 105.

Longuet-Higgins, M.S. (1970). Longshore currents generated by obliquely incident sea waves: 1. Journal of Geophysical Research 75, 6778-6789.

McCarroll, R. J., Brander, R. W., Castelle, B. and Scott, T. (2015). Simulating rip current escape strategies, Geomorphology.

McCarroll, R. J., Brander, R. W., Turner, I. L., Power, H. E., \& Mortlock, T. E. (2014). Lagrangian observations and circulation on an embayed beach with headland rip currents. Marine Geology, 355, 173-188.

MacMahan, J. H., Brown, J., Brown, J., Thornton, E., Reniers, A., Stanton, T., Henriquez, M., et al. (2010). Mean Lagrangian flow behavior on an open coast rip-channeled beach: A new perspective. Marine Geology, 268(1-4), 1-15. doi:10.1016/j.margeo.2009.09.011

MacMahan, J. H., Brown, J. and Thornton, E. (2009). Low-Cost Handheld Global Positioning System for Measuring Surf-Zone Currents. Journal of Coastal Research, 25(3), 744-754.

Murray, S. P. (1975). Trajectories and speeds of wind-driven currents near the coast. Journal of Physical Oceanography, 5, 347360.

Özölçer, I.H., Kömürcü, M.I., Birben, A.R. , Yüksek, Ö. and Karasu, S. (2006). Effects of T-shape groin parameters on beach accretion. Ocean Engineering, Vol. 33, 382-403.

Kraus, N. C., Hanson, H. and Blomgren, H. S. (1994). Modern Functional Design of Groin Systems. Proceedings of the $24^{\text {th }}$ International, Coastal Engineering Conference 1994, 1327-1342.

Pattiaratchi, C., Olsson, D., Hetzel, Y. and Lowe, R. (2009). Wave-driven circulation patterns in the lee of groynes. Continental Shelf Research, 29(16), 1961-1974.

van Rijn, L. C. (2011). Coastal erosion and control. Ocean \& Coastal Management, 54(12), 867-887.

Roelvink, D., Reniers, A., Van Dongeren, A., Van Thiel de Vires, J., McCall, R., and Lescinski, J. (2009). Modelling storm impacts on beaches, dunes and barrier islands. Coastal Engineering, 56, 1133-1152.

Schmidt, W. E., Woodward, B. T., Millikan, K. S., Guza, R. T., Raubenheimer, B. and Elgar, S. (2003). A GPS-Tracked Surf Zone Drifter. Journal of Atmospheric and Oceanic Technology, 20(7), 1069-1075.

Scott, T., Masselink, G., Russell, P.E. and Wooler, A. (2009). Beach morphodynamics and associated hazards in the UK. Unpublished PhD thesis, Plymouth University.

Scott, T., Masselink, G. and Russell, P. (2011). Morphodynamic characteristics and classification of beaches in England and Wales. Marine Geology, 286 (June 2010), 1-20.

Scott, T., Masselink, G., Austin, M. J. and Russell, P. (2014). Controls on macrotidal rip current circulation and hazard. Geomorphology, 214, 198-215.

Short, A.D. (1992). Beach systems of the central Netherlands coast: processes, morphology and structural impacts in a storm driven multi-bar system. Marine Geology $107(1-2), 103-132$.

Spydell, M., Feddersen, F., Guza, R. T. and Schmidt, W. E. (2007). Observing Surf-Zone Dispersion with Drifters. Journal of Physical Oceanography, 37(12), 2920-2939. 